Spring 3-6-2014

\title{
Mathieu de Morgues and Michel de Marillac: The Dévots and Absolutism
}

Caroline Maillet-Rao Ph.D.

Follow this and additional works at: https://via.library.depaul.edu/vhj

\section{Recommended Citation}

Maillet-Rao, Caroline Ph.D. (2014) "Mathieu de Morgues and Michel de Marillac: The Dévots and Absolutism," Vincentian Heritage Journal: Vol. 32: Iss. 1, Article 2.

Available at: https://via.library.depaul.edu/vhj/vol32/iss1/2

This Article is brought to you for free and open access by the Vincentian Journals and Publications at Digital Commons@DePaul. It has been accepted for inclusion in Vincentian Heritage Journal by an authorized editor of Digital Commons@DePaul. For more information, please contact digitalservices@depaul.edu. 


\section{Mathieu de Morgues and}

Michel de Marillac:

\section{The Dévots and Absolutism}

CAROLINE MAILLET-RAO, PH.D.

Translated by Gerard Cavanagh. Originally published in French History 25:3 (2011), 279-297, by Oxford University Press on behalf of the Society for the Study of French History. Reprinted by permission of the author and Oxford University Press, per License Agreement dated 11 July 2013. Editor's note: following the conditions set forth by Oxford University Press this article is republished as it appeared in French History, with no alterations. As such, the editorial style differs slightly from the method typically utilized in Vincentian Heritage. 
$\mathrm{T}$ he dévots, the Queen Mother Marie de Médicis' party represented by Mathieu de Morgues (1582-1670) and Michel de Marillac (1560-1632), are known as the most ferocious adversaries of Louis XIII's principal minister, Cardinal Richelieu. The Day of the Dupes marked the end of their influence in France but not the end of their activity, since they continued in exile to protest against and denounce the cardinal's iron grip on French political life. Mathieu de Morgues was the great defender of the dévot party's position, which he explained in a series of tracts begun in 1617 and continued until the time of the Fronde in 1650. Head of the dévot party, Michel de Marillac held the office of garde des sceaux from 1626 until 11 November 1630. His political thought is set out in several documents which he drew up while carrying out his functions. These include three as yet unpublished treatises - one on the role of the Parlements, another on the Conseil du roi and the third on the office of chancellier - an unpublished speech "sur le bon gouvernement," his only partly published opinion paper on France's entry into the Thirty Years War, and finally his voluminous correspondence with Cardinal-Minister Richelieu, also only published in part. ${ }^{1}$

The dévot party members' political thinking has been the subject of new interpretations which have not, however, invalidated older viewpoints. As a result, it has been impossible to determine whether the dévots were first and foremost bons français or bons catholiques. ${ }^{2}$ They have always been said to be at once ultramontane, pro-Spanish and favorable to limited monarchy, even though it has been demonstrated that de Marillac's absolutism and de Morgues' Gallicanism were evident in the affair of Bellarmin's condemnation in 1621. ${ }^{3}$ At the same time, Cardinal Richelieu's backers are presented as Gallicans, hostile to the Habsburgs and Spain, and favorable to the emerging absolute monarchy. The idea of the difference between the dévot party and that of Richelieu being that of an opposition

\footnotetext{
1 M. de Marillac, Mémoire dressé par le garde des sceaux de Marillac principalement contre l'autoritédu Parlement (B [ibliothèque] N[ationale de] F[rance], MS fr. 7549); M. de Marillac, Traité du Conseil du Roi, (A[rchives] N[ationales], U 955 a); M. de Marillac, Traité des chanceliers et gardes des sceaux de France, (AN, U 948); M. de Marillac, Discours sur la manière de gouverner l'Etat (10 June 1630, A[rchives des] A[ffaires] É[trangères], Mémoires et Documents, France, 792, fos 207-14); M. de Marillac, Mémoire du 20 juillet 1630 (AAE, Correspondance politique, Sardaigne, 12, fos 480-4); P. Grillon (ed.), Les Papiers de Richelieu (Paris, 1980).

2 L. Avezou, "Richelieu vu par Mathieu de Morgues et Paul Hay de Chastelet," Travaux de littérature, 18 (2005), 167-78; D. A. Bailey, "Power and piety: the religiosity of Michel de Marillac," Canad Jl History/Annales canadiennes d'histoire, 42 (2007), 1-24; "Introduction" to Lefèvre sieur de Lezeau, Nicolas, La vie de Michel de Marillac (1560-1632). Garde des sceaux sous Louis XIII, transcribed and ed. D. A. Bailey (Québec, 2007), xxv-lxx; S. Hwi Lim, "Mathieu de Morgues, bon français ou bon catholique?", XVIIe siècle, 213 (2001), 655-72; S-M. Morgain, "La disgrâce de Michel de Marillac," Histoire et archives, 7 (2000), 49-69.

3 D. A. Bailey, "The family and early career of Michel de Marillac (1560-1632)," in Society and Institutions in Early Modern France, ed. M. P. Holt (Athens, GA and London, 1991), 170-89; Bailey, "Power and piety"; Y.-M. Bercé, Les Monarchies espagnole et française du milieu du XVIe siècle à 1714 (Paris, 2000), 55; Y. Durand, "Mystique et politique au XVIIe siècle: l'influence du Pseudo-Denys," XVIIe siècle, 173 (1991), 326; S. Hwi Lim, "La pensée politique des 'bons catholiques' dans la première moitie du XVIIe siècle" (thèse de doctorat, Paris IV, 1998), 389-458; J. Russell Major, Representative Government in Early Modern France (New Haven, 1980); H. Duccini, Faire voir, faire croire. L'opinion publique sous Louis XIII (Paris, 2003), 453-4.
} 


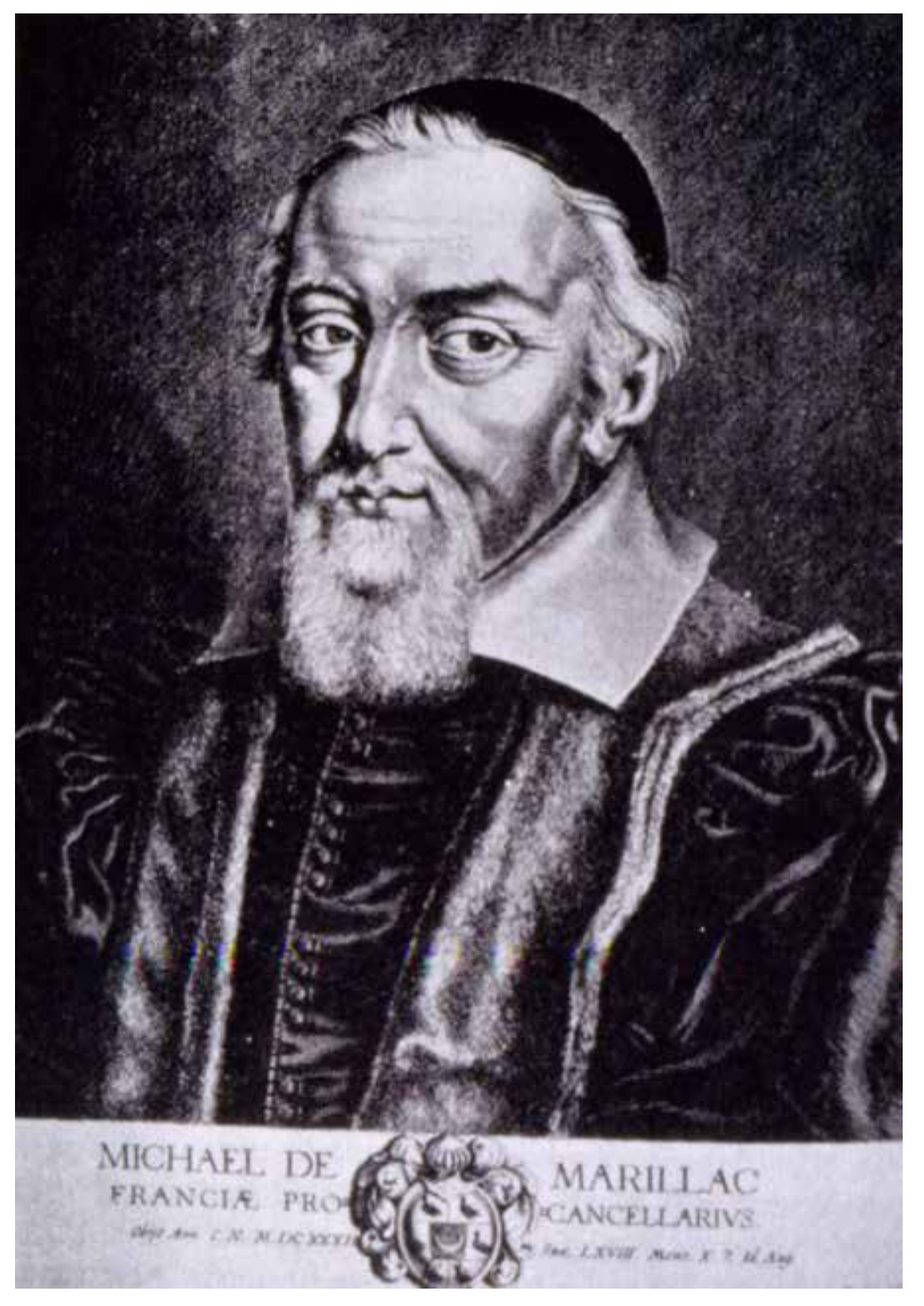

Portrait of Michel de Marillac (1560-1632).

Image collection of the Vincentian Studies Institute

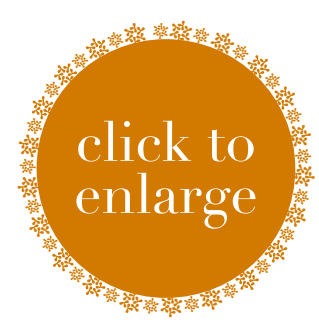

between traditionalists and absolutists is still accepted. ${ }^{4}$ First, because Mathieu de Morgues is perceived as having been opposed to the establishment of an absolute monarchy, and secondly, because no one has questioned the idea of the members of the dévot party being pro-Spanish. ${ }^{5}$ On the contrary, the latest studies on the dévots have insisted that, in the area of foreign policy, de Marillac was opposed to war with Spain and the Habsburgs out of a desire to preserve Catholic, rather than state, interests. ${ }^{6}$ Ultimately, these studies validate the traditional thesis of Georges Pagès, who thus remains the authority on the subject.

\footnotetext{
${ }_{4}$ On the controversial concept of absolutism, see R. Bonney, L'Absolutisme (Paris, 1989); F. Cosandey and R. Descimon, L'Absolutisme en France. Histoire et historiographie (Paris, 2002); J. Cornette, "L'histoire au travail. Le nouveau siècle de Louis XIV: un bilan historiographique depuis 20 ans (1980-2000)," Histoire, Économie et Société (2000), 561-605; D. Crouzet, "Langage de l'absoluité royale (1560-1576)," L'Absolutisme, un concept irremplaçable? Une mise au point franco-allemande (Munich, 2008). According to contemporary ideals of absolute monarchy, political decisions should strictly originate from the king's will according to the doctrine of divine right. Only the king is entitled to determine God's will and to establish the kingdom of God on earth. Yet, far from being tyrannical, such a regime had to operate within particular constraints. These included: the observance of divine law; the enforcement of the kingdom's fundamental laws; and acceptance of the highly regulated right of remonstrance by which kings agreed to take into account their humble subjects' opinions.

5 G. Pagès, "Autour du grand orage. Richelieu et Marillac: deux politiques," Revue historique, 179 (1937), 63-97; Duccini, Faire voir, faire croire, 453-4; Lim, “La pensée politique," 669.

6 Bailey, "Power and piety," 1-24; Morgain, “La disgrâce de Michel de Marillac," 49-69.
} 
As is evident in this analysis of the historiography on the dévot party's political thought, the whole question needs to be revisited, because the dévots' thinking is not as incoherent as it is often portrayed. Nor are the criteria mentioned above, designating the political actors of Louis XIII's reign as either good Catholics or good Frenchmen, helpful: we need to critique the position of these same actors on the question of the ministeriat. ${ }^{7}$ Indeed, as recent studies on de Marillac's absolutist tendencies have shown, the differences between the dévot party's and Richelieu's political thinking were not as radical as historians have suggested, and scholars have rightly demonstrated certain points of convergence between the two positions. Going one step further, it may be contended that the members of the dévot party, judging by its attitudes towards the monarchy, the Church and foreign policy, would number among the 'good Frenchmen,' their opposition to Richelieu having had less to do with the defense of traditional monarchy than with their opposition to the establishment of a principal minister. ${ }^{8}$

While the dévot party's opposition to Cardinal Richelieu's ministry was based on different arguments relating to ideas on monarchy, on royal government and on domestic and foreign policy, the thesis presented here has to do instead with its conception of sovereignty. Despite Michel de Marillac's status as head of the party, we shall begin by analysing the arguments made by Mathieu de Morgues, because of the greater detail and clarity of his thoughts, before considering those of de Marillac.

\section{I}

The concept of monarchical sovereignty appeared from the beginning as a vision of absolute power held by virtue of divine right. Indeed, medieval jurists defined kings as God's lieutenants on earth and added that, for this reason, they were accountable to no one else. The prince was thus not subject to the law, meaning the law of his predecessors, in conformity with the principle princeps legibus solutus from Ulpian's Digest. In the fourteenth century, these doctrines were used to reinforce royal power and affirm the king's pre-eminence. However, royal sovereignty was not yet conceived of as absolutist, but rather from the perspective of the enumeration of kingly rights. According to Charles de Grassaille, regalian rights were no longer seen as privileges but as the king's rights. He dispensed with any idea of concession on the part of the people, the princes or the pope. ${ }^{9}$ Purged in this way of discussions of the origin of the attributes of sovereignty, medieval legal doctrine was ready to be used by the great absolutist thinkers.

Developed by the members of the politique party, the doctrine of absolute sovereignty was based on a voluntarist conception of power. According to Jean Bodin, commands

\footnotetext{
7 C. Maillet-Rao, “La théologie politique des dévots Mathieu de Morgues et Michel de Marillac, opposants au cardinal de Richelieu," Renaissance and Reformation/Renaissance et Réforme, 32 (2009), 51-77.

8 C. Maillet-Rao, “Mathieu de Morgues (1582-1670) et Michel de Marillac (1560-1632): les dévots devant l'Histoire" (thèse de doctorat, Tours, 2004), to be published as La pensée politique des dévots Mathieu de Morgues et Michel de Marillac. Une opposition au ministériat du cardinal de Richelieu.

9 G. Leyte, “Charles de Grassaille et la monarchie française," Pensée politique et droit (Aix-Marseille, 1998), 315-26.
} 
derive only from the sovereign's will: “Les lois du prince souverain ores [sic] qu'elles fussent fondées en bonnes et vives raisons, néanmoins elles ne dépendent que de sa pure et franche volonté," the latter thus implying the indivisibility of power. ${ }^{10}$ This doctrine was the consequence of the challenges to royal power made by monarchomachs and parlementaires alike. ${ }^{11}$ For his part, Cardin le Bret had deduced from divine right the absolute independence of royal power from both the Holy See and the Holy Roman Empire. By an argument extracted from the indivisibility of sovereignty, he definitively rejected the emperor's claims and submitted his whole kingdom to obedience. ${ }^{12}$ Cardin le Bret based himself on French and European history to refute the theses of the Jesuit theologian Jacques Keller, author of the famous pamphlets of 1625, the Mysteria politica and the Admonitio ad regem. The Mysteria denounced the foreign policy conducted by France and counseled by Richelieu. Keller defended the rights of the house of Austria, positioning it as champion of the interests of Catholic Christianity. In contrast, the Admonitio demonstrated with great vehemence that the cardinal was responsible for a policy leading to the ruin of Catholicism and the triumph of the Protestant party. Exactly mirroring the Catholic Leaguers' ideas of the sixteenth century, the author recognized the temporal power of the pope to solve the international crisis by excommunicating the king and his ministers. The author also called for popular rebellion, thereby demonstrating his approval of subjects' right to resist. ${ }^{13}$ Obviously, these ideas went against those of the absolutist movement in France promoted by the politiques, one of whom was Le Bret. It is thus no surprise that he firmly opposed them, on the basis of both French and European history, going back to the time when France dominated Europe and possessed the empire. Then, he distinguished the Roman Empire from the contemporary one to deny the influence claimed by the latter by virtue of being the heir of the former. It was thus never a question of the kingdom of France sharing its power or submitting it to another superior authority.

In line with the thinking of the politiques, the goal of the third estate's actions at the Estates General of 1614 was the defense of the total sovereignty of the king against pontifical claims. ${ }^{14}$ In the same vein, the dévot party thinkers de Morgues and de Marillac responded to what they saw as a threat to royal authority by brandishing the doctrine of absolute sovereignty.

\footnotetext{
${ }^{10}$ J. Bodin, Les six livres de la République (1576), i, ch. 8 (Paris, 1986).

${ }^{11}$ Descimon and Cosandey, L'absolutisme, 43; and O. Beaud, La Puissance de l'État (Paris, 1994), 72, 133.

${ }_{12}$ C. le Bret, De La Souveraineté du roi (1632), in Les Oeuvres de Messire C. le Bret (Paris, 1689), 5-6. Cf. G. Picot, Cardin le Bret et la doctrine de la souveraineté (Nancy, 1948), 141, 144-5.

${ }^{13}$ É. Thuau, Raison d'État et pensée politique à l'époque de Richelieu (Paris, 2000), 110-13; on the Jesuits' conception of the state, R. Bireley, "Les jésuites et la conduite de l'État baroque," in L. Giard and L. de Vaucelles (eds), Les Jésuites à l'âge baroque (1540-1640) (Paris, 1996), 229-42.

${ }^{14}$ R. Mousnier, L'Assassinat d'Henri IV. Le problème du tyrannicide et l'affermissement de la monarchie absolue (Paris, 1992 edn), 348 .
} 


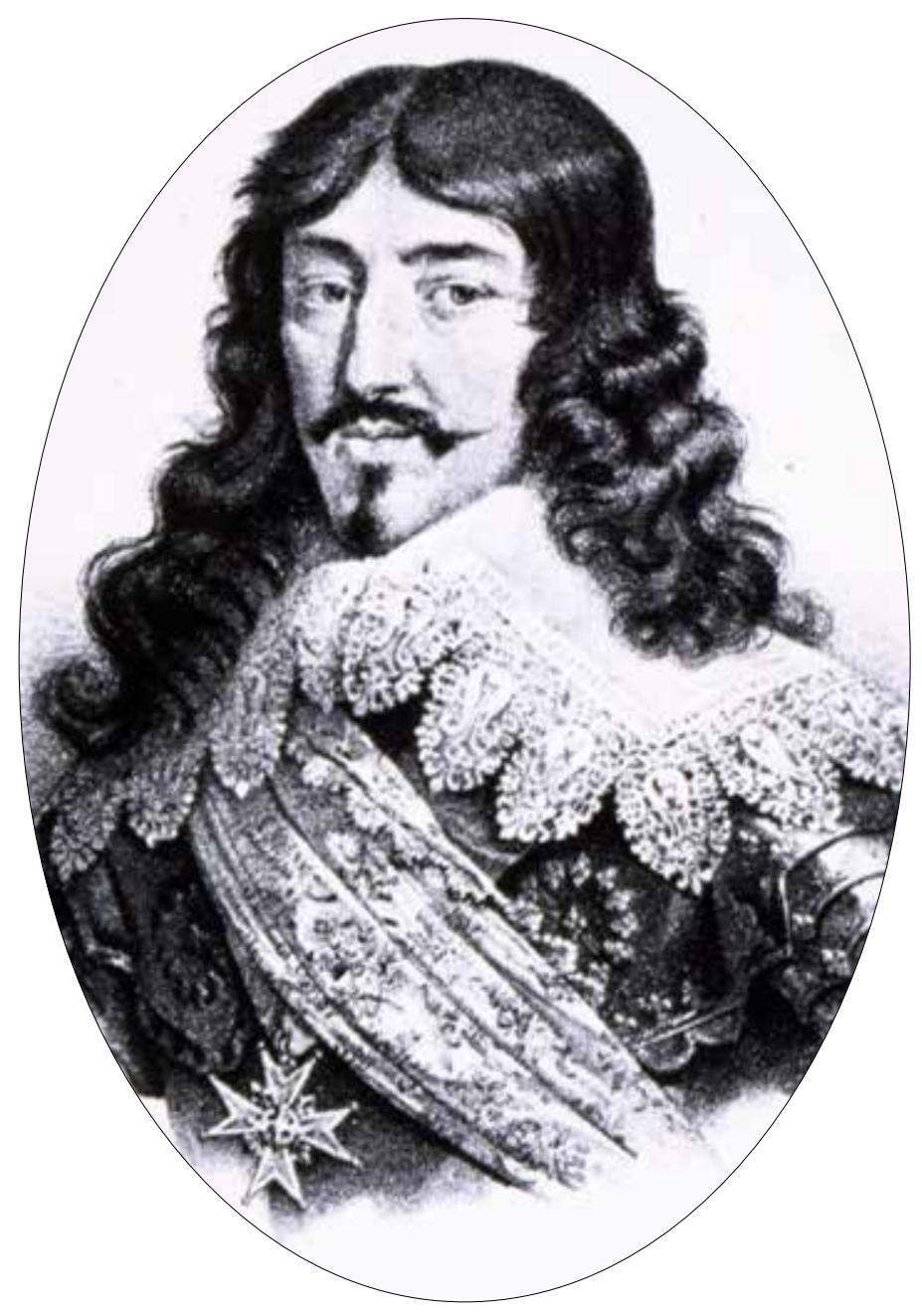

Portrait of Louis XIII (1601-1643). He ascended to the throne in 1610, at the age of eight-and-a-half, following the assassination of his father.

Image collection of the Vincentian Studies Institute

click to enlarge

Mathieu de Morgues has gone down in history as having virulently denounced Cardinal Richelieu's 'tyranny. ${ }^{15}$ In fact, this criticism derived from a determinedly political opposition to the ministériat, that is, to what de Morgues defined as the system of government in which control of the kingdom is delegated to a principal minister. Devised by the cardinal himself, the theory of ministériat defended the idea that the king could hand over the government of his kingdom to a premier ministre, this latter then theoretically enjoying the widest of powers well in excess of counseling the king. Richelieu even bestowed a quasi-divine foundation on this delegation of power by considering that if the king did not himself wish to govern, it was the will of God that he should entrust a principal minister with this charge. And, in fact, Richelieu saw himself as the instrument of God. In this way, the minister exercised many functions involving the king's sovereign power. For de Morgues, this idea was totally contrary to the spirit of the theory of absolute monarchy. It was nothing less than an attempt to usurp royal authority that could not, in any case, even if the king wanted it, be transferred to a principal minister. The king's power was every bit as indivisible for de Morgues as it was, for example, for his contemporary Cardin Le Bret, who justified absolute royal power by arguing that sovereignty was no more divisible than a geometric point. The defense of absolute monarchy is thus at the heart of this critique of

${ }^{15}$ J. Bergin, “Three Faces of Richelieu: A Historiographical Essay,” Fr Hist, 23 (2009), 533. 
Richelieu's ministériat, which it regarded as tyrannical. Therefore, de Morgues' opposition constituted not a rejection of the practice of absolutism by Louis XIII's government, but rather a demand that the king exercise power alone. ${ }^{16}$

For this reason, insofar as it is founded on the idea of the usurpation of royal power by a minister, de Morgues' criticism of Richelieu's tyranny does not appear to have been a simple repetition of the refrain of the bad counselor. ${ }^{17}$ This historiographical commonplace assumes that criticism of the king's advisers is nothing more than an indirect way of attacking the king's absolutist policies. ${ }^{18}$ This thesis could be entertained if de Morgues had not himself been in favor of absolutism. Besides, he was manifestly hostile to all favorites, including Mazarin, starting with those of Marie de Médicis, the Concinis:

Votre Majesté eut avis que deux personnes étrangères, qui étant comblées en France de toutes sortes de biens et d'honneurs, s'étaient tellement aveuglées en leur ambition, qu'abusant du pouvoir et de l'autorité qu'on les estimait être la seule cause de toutes nos calamités. A quoi V.M., comme un Hercule vengeur, sut généreusement remédier [....] V.M. a recueilli favorablement tous ses sujets prosternés à ses pieds [...] et, montant sur son trône, elle a voulu mettre le sceptre en sa seule main, pour régir ses peuples à l'avenir. ${ }^{19}$

Thus de Morgues quite rightly appreciated the king taking back power for himself in 1617 and imposing himself as king by a coup d'état on 24 April 1617. For some time by then, the domination of the Maréchal d'Ancre, Sieur de Concini (1575-1617), and his wife, Léonora Galigaï (1568-1617), the regent's favorites, had become intolerable. The princes, lords and nobility had been the first to react by leaving Paris and taking up arms, mustering their troops under the duc de Nevers and the duc du Maine. Then it was the turn of the council members, Richelieu and Barbin, to make known their discontent by resigning. But it was Louis XIII himself who took the initiative in the coup d'état. The young king intended to arrest Concini, incarcerate him in the Bastille and have him judged by the Parlement, but the maréchal instead met his death under a porch at the Louvre. Having pulled off this coup, the king had Marie de Médicis isolated and began to exercise power himself. ${ }^{20}$ If de Morgues approved of the king taking back power in the name of royal sovereignty, he did

\footnotetext{
${ }^{16}$ Maillet-Rao, “La théologie politique," 51-77.

${ }^{17}$ Contra Lim, "La pensée politique," 306.

${ }_{18}$ P. Bénichou, Morales du grand siècle (Paris, 1990 edn), 80-1. On the other hand, in A. Jouanna, Le devoir de révolte (Paris, 1989), 237-9, this interpretation is contested by showing that the aristocrats' claims were not motivated by a wish to share power.

${ }^{19}$ I am grateful to one of the assessors of this article for having brought to my attention the fact that de Morgues authored a Mazarinade, as pointed out in R. Bonney, "Cardinal Mazarin and his critics: the remonstrances of 1652," Jl European Stud, 10 (1980), 18-19. M. de Morgues, Consolation aux bons français (1618), 17-18.

${ }^{20}$ Duc de Chaulnes, "Relation exacte de ce qui s'est passé à la mort du maréchal d'Ancre," in MM. Michaud et Poujoulat, Mémoires pour servir à l'histoire de France (Paris, 1837).
} 


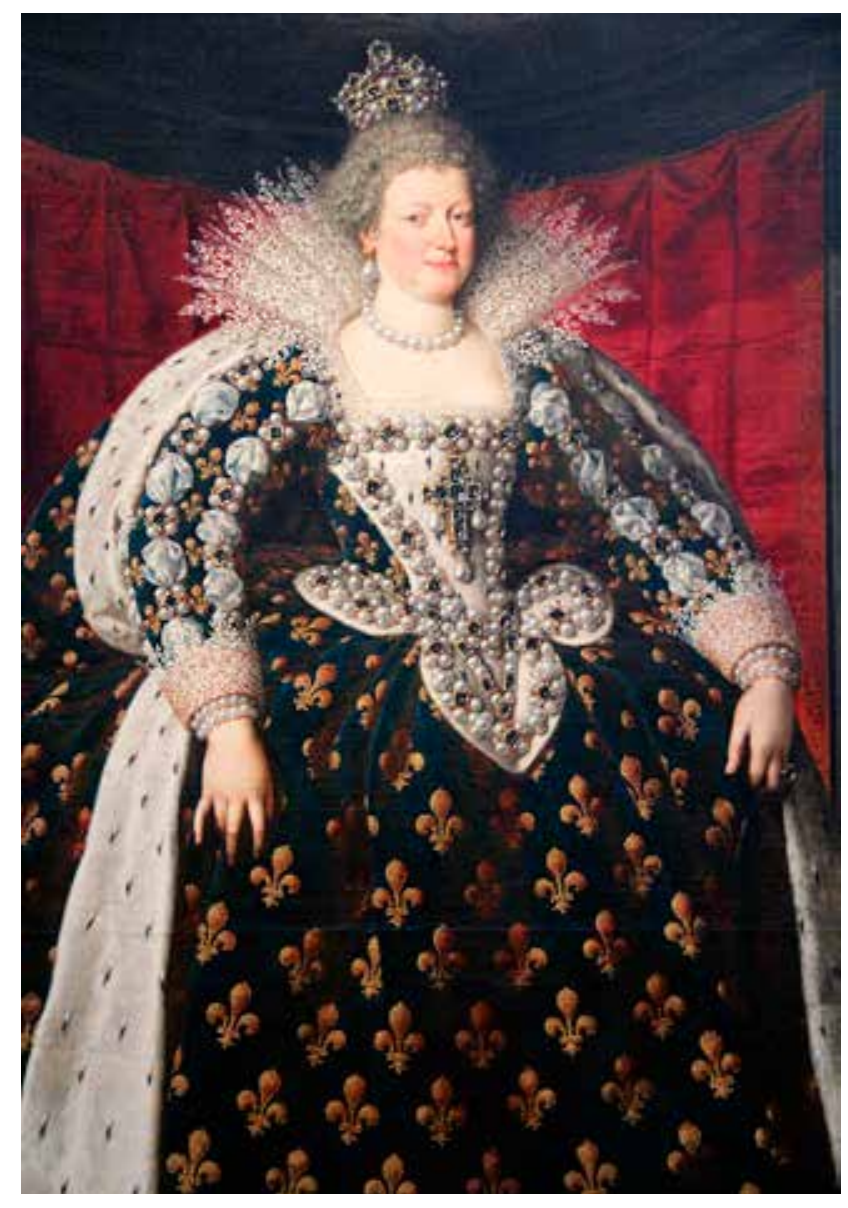

Marie de Médici, Queen of France (1573-1642). Painting by Frans

Pourbus the younger.

Public Domain

click to

enlarge

not go so far as to blame the ex-regent, his mistress, for the Concinis' faults. The Concinis received all the blame, having been blinded by the queen mother's favors and carried away by their ambition. In fact, de Morgues did not appreciate Marie de Médicis' exile from Paris, writing: “Je ne doute point, Sire, que vous n'ayez témoigné votre bonté, lorsque vous avez prié la reine votre mère de se retirer [...] et ma raison est que l'expérience du passé nous enseigne que les serviteurs qui se sont voulus emparer des personnes de leurs maîtres, pour gouverner tous seuls, les ont toujours soustraits à leurs pères et mères." ${ }^{21}$ In de Morgues' opinion, this decision was made under the influence of the new favorite, the duc de Luynes (1578-1621).

At any rate, it was the ambition of favorites that, in de Morgues' view, constituted the real danger for the monarchy, but not everyone went so far as to try to introduce a new institution into monarchical theory. This was why de Morgues counseled the king against trusting anyone because favorites are always inclined to take advantage of such trust for usurping royal power. ${ }^{22}$ He argued that this was the case with the Concinis, de Luynes and, above all, Richelieu, who did not hesitate to use his lies to persuade the king to make certain

\footnotetext{
${ }^{21}$ De Morgues, Vérités chrétienne au Roi très-chrétien (1620), 7.

22 “Les desseins de ceux qui ont l'honneur d'approcher les grands princes ne montent toujours, et qu'après s'être donnés créance auprès de leurs maîtres ils ne les portent à tout entreprendre. Il y en a peu qui le fassent pour avancer leur gloire, mais pour leur témoigner qu'ils leur sont tout à fait nécessaires, et de là s'acquérir une autorité dans leurs actions, dont bien souvent ils abusent": de Morgues, Charitable remontrance (1631), in Recueil des diverses pièces pour la défense de la reine mère du roi très-chrétien Louis XIII (1643 edn), i. 247.
} 
decisions, especially ones concerning the queen mother. ${ }^{23}$ Taking advantage of his master's benevolence, according to de Morgues, Richelieu even exercised the king's absolute power through the deployment of different sovereign duties. "C'est lui qui de puissance absolue met et destitue les capitaines et autres officiers, qui ordonne des monstres, qui a fait fondre grand nombre de canons, qui ne portent point d'autres écussons que les siens, et qui a pris tous les titres et marques de la souveraineté partout où il n'y a que votre lieutenance." ${ }^{24}$ He had thus exceeded his ministerial powers, which consisted of supervising different hierarchies, the stimulation and assistance, when necessary, of those hierarchies, as well as intervention in the exceptional or periodic affairs that put in danger political unity, social order, the common weal, the great royal interests and the laws. These powers were distinct from the satisfaction of current, regular and particular public needs. ${ }^{25}$ Furthermore, de Morgues felt that Richelieu had also usurped the king's authority over justice during the trial of Louis de Marillac (1572-1632):

S'il est devenu traître en Piedmont, au même instant que la reine votre mère a fait paraître à Paris sa juste indignation, il ne faut point faire de difficulté de renvoyer la connaissance au Parlement, où les officiers de votre couronne doivent être jugés, ni appréhender d'exécuter le criminel en la place de grève. Ses amis ne sont pas si puissants qu'il faille qu'on l'ôte à votre justice. Tout votre peuple la louera et les grands de votre royaume seront instruits par cet exemple, qu'il faut être fidèle à son roi et à son pays. En toutes ces choses que j'ai représentées à V.M., elle ne peut être blâmée ni d'injustice [...]; les juges qui envoient au supplice un innocent ne sont point coupables mais ceux qui accusent ou qui ont déposé faussement. Sire, vous êtes le juge souverain de tout votre peuple. ${ }^{26}$

A loyal military man, Louis de Marillac, brother of the garde des sceaux, was elevated to the dignity of marshal of France in 1629 in recognition of his services and sent to Italy in 1630 as a lieutenant general. After the Day of the Dupes, that de Morgues evokes here as the day when the queen mother "manifested her indignation," he was arrested at his camp at Felizzo in Piedmont on 30 November 1630, by Marshal Schomberg, charged with notifying him of the king's order. Brought back to Paris, he was condemned to death after eighteen months of procedure by an extraordinary court made up of judges chosen by Richelieu. Louis de Marillac was beheaded on the place de Grève on 10 May 1632, and buried at the Feuillants' Church. De Morgues affirms that the king's justice should have been exercised by the Parlement as sovereign court. After having examined the affair, the Parlement could have decided to execute the accused for disobedience to the king. But far from this being

\footnotetext{
23 “Tout cela est suivi d'une déclaration infâme, des saisies des rentes et des meubles [...] pour réduire[...] la plus grande princesse du monde à une extrême nécessité [....] Pour vous porter [...] à permettre qu' on se soit couvert de votre autorité et de votre nom, il faut qu'on ait employé des suppositions et calomnies": de Morgues, Très-humble remontrance au Roi (1631), in Recueil des diverses pièces, 16.

${ }^{24}$ De Morgues, Très-humble remontrance au Roi, 38.

${ }^{25}$ R. Mousnier, Les Institutions de la France sous la monarchie absolue (Paris, 1990 edn), 457.

${ }^{26}$ De Morgues, Très-humble remontrance au Roi, 42.
} 


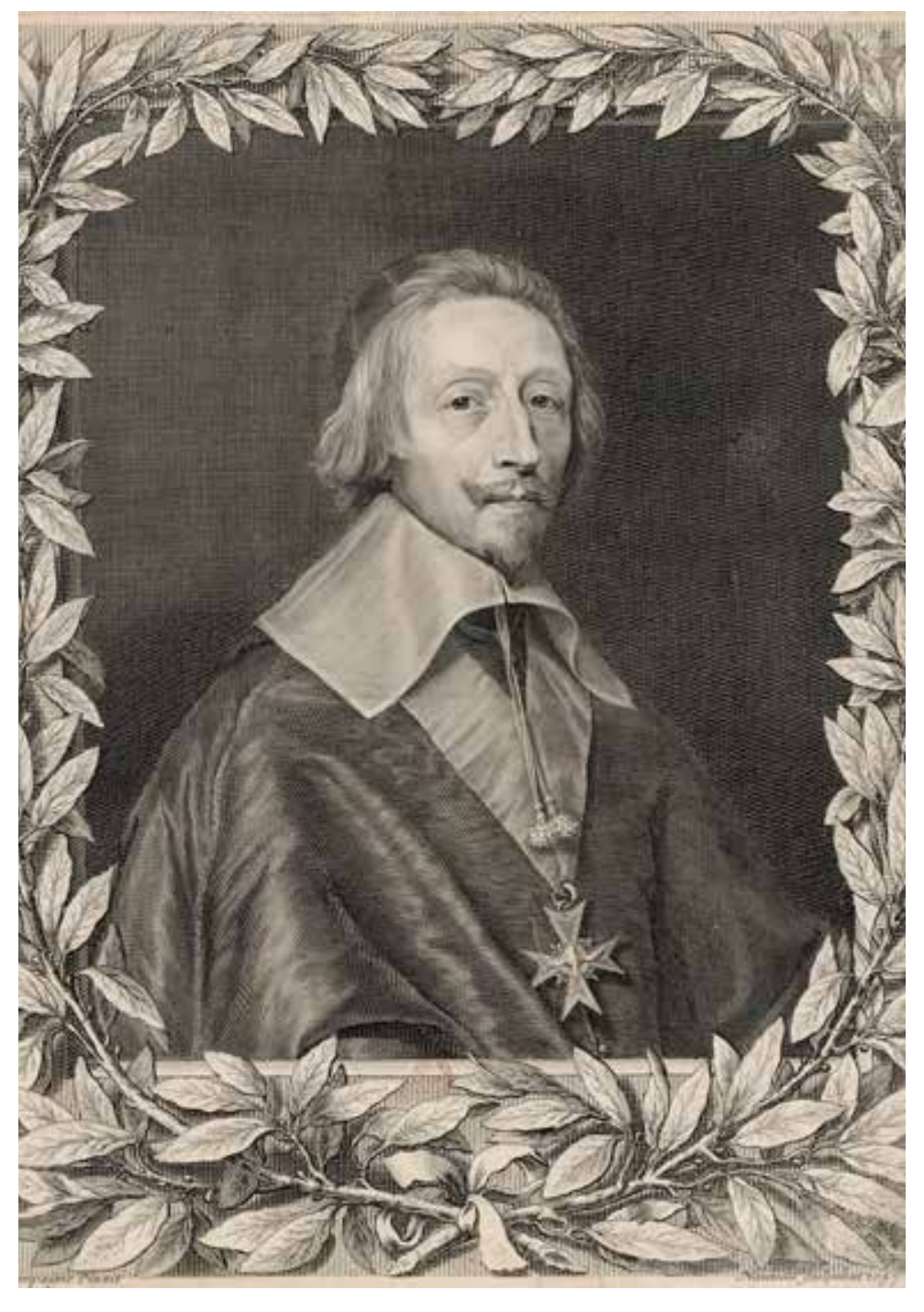

Engraved portrait, dated 1657 , of Cardinal Richelieu (1582-

1642). Artist Robert Nanteuil.

Public Domain

click to

enlarge

the case, according to de Morgues, those who judged and executed Marshal de Marillac were not exercising the king's justice but that of Richelieu, who wanted to get rid of his rivals. There was no other reason for establishing an extraordinary court while there was already a court charged with exercising justice in the name, and under the supervision, of the king. ${ }^{27}$ By advancing the reason of the king's absolute power, in this case in order to criticize the use of favorites in the kingdom's government, Mathieu de Morgues showed himself to be favorable to absolutism.

II

It could be asserted in response, however, that sovereignty has always been absolute in its conception, even when the functions of monarchy were restricted. The fact that de Morgues stressed the king's absolute sovereignty would not necessarily mean that he looked favorably on absolutism. Also, de Morgues did not propose, as did Bodin, a formal definition of sovereignty. ${ }^{28}$ Instead, he gave a substantial and, thus, more traditional definition, listing the rights and prerogatives essential to the existence of this sovereignty. For de Morgues, the power to make laws, to decide on expenditure and to declare war were exclusively regalian rights: "Ce sont ceux-là, Sire, qui se veulent emparer de votre État, qui ont en leur disposition votre sceau, votre plume, vos finances, vos canons, vos

\footnotetext{
27 De Morgues, Charitable remontrance, 329.

${ }^{28}$ Beaud, La Puissance de l'État, 139-43.
} 
vaisseaux, et vos principales places maritimes et frontières, qu'ils tâchent à vos dépends de rendre imprenables à vous-même." ${ }^{29}$ Indeed, these same usurpers covet "la justice aussi par laquelle seuls les rois règnent absolus." ${ }^{30}$ None but the king can make use of political successes. ${ }^{31}$

Although de Morgues did not adopt a formal definition of sovereignty, he did not envisage that its exercise could be shared since it was founded exclusively on the king's will. Thus, de Morgues saw the voluntarist concept of power developed by Bodin as characterizing absolutism and did not, therefore, take lightly its central importance for the raison d'état. ${ }^{32}$ In a long and extremely interesting passage, reproduced here in its entirety given its importance in the author's work, de Morgues set out a theory of monarchy founded on the king's will and, for this reason, perfectly compatible with that of absolute monarchy:

Tant s'en faut [il est peu probable] que ce délai ait blessé l'une [l'autorité] ou l'autre [la réputation], comme on a voulu persuader, pour vous porter à employer le pouvoir absolu. C'est une pièce que vous ferez jouer quand il vous plaira. Mais jamais homme de bien, ni serviteur fidèle ne vous conseillera de la faire valoir que dans une grande extrémité. Et afin que V.M. soit pleinement informée de cette vérité, qui est de très grande importance, il est nécessaire de vous représenter pour quelle considération nos bons et justes rois ont établi les Parlements, et autres cours souveraines. Ils leur ont donné le pouvoir de vérifier leurs édits, déclarations et lettres patentes, avec permission de leur faire leurs très-humbles remontrances sur la conséquence de ce qui leur est adressé pour être examiné par eux, non pour être simplement enregistré, ce qui n'est l'office que des greffiers. Ce n'est pas, Sire, que ces corps soient les contrôleurs de vos actions ou tuteurs des rois, qu'ils aient une puissance par dessus la vôtre et soient comme tribuns du peuple. Ceux qui les voudraient rendre odieux le veulent faire croire, ou peut-être quelques particuliers de ces compagnies qui ignorent leur institution se sont imaginés cela, et le peuvent avoir dit. Il est vrai Sire, qu'ils sont tous vos sujets, et vos officiers, ils n'ont point de puissance que celle qu'ils tiennent de vous, et ne doivent user d'aucune répartie, quand vous

\footnotetext{
29 De Morgues, Très-humble remontrance au Roi, 18.

30 De Morgues, Consolation aux bons français, 27.

31 “Ce sont ceux-là, Sire, qui vous dérobent votre gloire, qui payent des écrivains pour faire publier partout, qu'eux seuls ont pris la Rochelle, et dompté les rebelles, qu'ils ont battu l'empereur, les rois d'Espagne et d'Angleterre, et le prince de Piedmont, qu'ils ont conquis le pays du dernier, sauvé celui de Mantoüe, et secouru Cazal": de Morgues, Très-humble remontrance au Roi, 17-18.

${ }^{32}$ In this other case, when the king might have decided to punish the cardinal's partisans for abuse of power - an unlikely hypothesis in light of historical events - de Morgues warned the latter that they would eventually have reason to fear the king's will: "Parce qu'ils ont sujet de craindre celle [la justice] qui a la puissance, et qui aura bientôt la volonté de la châtier [leur malice]": de Morgues, Vrais et bons avis d'un françois fidèle (1631), in Recueil des diverses pièces, 118. Thuau, Raison d'État, 128.
} 
commandez en Maître. Mais vous me permettrez, s'il vous plaît, de vous dire un secret qui vous a été caché. Les bons rois vos prédécesseurs avaient appris, ce que les anciens politiques ont écrit, et que toutes les histoires des empires du monde ont confirmé, que les monarchies qui n'avaient point de tempérament d'aristocratie, étaient de petite durée parce qu'elles se rendaient premièrement suspectes et après odieuses aux peuples qui leur donnaient un mauvais nom. Nos rois ont voulu fuir non seulement l'effet mais le soupçon, ils aperçurent que les lois de leur État et la soumission des français, leur acquerraient une entière disposition de la vie et des biens de leurs sujets, et même de faire des nouveautés, impositions, créations d'offices, et déclarations, selon le rencontre et la nécessité des affaires. Pour faire recevoir ces choses avec plus de raison et apparence de justice, ces mêmes rois se soumirent volontairement à les faire examiner et vérifier par les cours souveraines tant pour la décharge de leur conscience devant Dieu, que pour celle de leur réputation devant les hommes, se réservant toujours d'user de l'autorité absolue, conformément à ces mots qu'ils mettent en toutes leurs lettres patentes et édits: Tel est notre bon plaisir. Les bons princes, comme vous, se contentent de faire écrire ces paroles sur le parchemin, pour montrer leur puissance, ils ne se servent jamais de tout le droit de souveraineté, qui doit être bien ménagé, et ne le saurait mieux être qu'en suivant les chemins ordinaires, qui font aimer comme bon, et estimer comme juste celui qui les tient. Au contraire, on murmure contre celui qui les quitte, et on a mauvaise opinion de son gouvernement, ce qui dispose les esprits à la rébellion. ${ }^{33}$

Certainly, the concept of sovereignty founded on the king's will does not laicize power because decisions are still made in a spirit of respect for divine law and divine will, but does this same concept make the exercise of royal power any harsher? ${ }^{34}$ It is true that royal government runs the risk of becoming tyrannical given how much power the king has: “Vous [...] soutenez que tout ce qu'on veut est équitable, parce qu'on le peut [...] vous seriez bien marri, qu' on vous fît fouetter par cette règle, et diriez bientôt que c'est une tyrannie." ${ }^{35}$ But royal power is not tyrannical because the king only makes use of it when he judges it necessary. This conception is in strict accordance with the exercise of power in an absolute monarchy, as indicated by the following words of Louis $\mathrm{XV}$, spoken at the Flagellation Session: “Le spectacle scandaleux d'une contradiction rivale de ma puissance souveraine me réduirait à la triste nécessité d'employer tout le pouvoir que j’ai reçu de Dieu pour preserver mes peuples des suites funestes de ces entreprises." 36 The two texts, of de Morgues and Louis XV, both written in circumstances of parlementaire resistance,

\footnotetext{
${ }^{33}$ De Morgues, Très-humble remontrance au Roi, 76-9.

${ }^{34}$ Contra Thuau, Raison d'État, 120.

35 De Morgues, Vrais et bons avis d'un français fidèle, 173.

36 Séance royale dite de la flagellation, 3 March 1766, Remontrances du parlement de Paris au XVIIIe siècle (MM. Flammermont and Touneux, Collection des documents inédits sur l'histoire de France; Paris, 1895), ii. 558.
} 
saw monarchical power in the same way, namely, as an omnipotent power justly and moderately used. According to Louis XV, government founded on the king's will cannot be abusive because the king governs in accordance with the spirit of monarchy which is "l'esprit de conseil, de justice et de raison." ${ }^{37}$ It is the same for de Morgues. The limits constituted by the subjects' right of remonstrance and the obligation to make just decisions must not be construed as impediments on the king's absolute power. Yet absolutism is not the exercise of an unlimited and laicized power. It must take account of its limits which are an inherent part of the functioning of absolute monarchy.

Mathieu de Morgues' thought is thus compatible with the theory of absolute monarchy in that it posits a sovereign power which is absolute but not unlimited. For him, the Parlement's right of remonstrance is never equivalent to a form of control over the king's decisions. Thus, it is inaccurate to contend that de Morgues considered the Parlement a sort of regulator of absolute power, or even as the representative of the constituent states of the nation, acting in every case as a hindrance to absolute power. ${ }^{38}$ The king did not need to "avoir obligatoirement leur concours"; on the contrary, he could impose on them any decision whatsoever. ${ }^{39}$ That is why de Morgues counseled the king to retain this limit on the right of remonstrance in spite of the superiority of his power, out of a concern for justice. The maintenance of this limit does not cast doubt on de Morgues' absolutism, it helps to distinguish absolute monarchy from tyranny, rather than from limited monarchy. Indeed, founded on his will, the king's decisions could not constitute tyranny since the king knew the monarchy's limits:

Vous ramassez grand nombre de défenses faites aux Parlements de se mêler des affaires d'État, nous ne doutons pas de la puissance que les rois ont sur les officiers. Ceux qui les peuvent établir, interdire et destituer, peuvent à plus forte raison borner leur autorité mais vous qui êtes si savant en l'écriture sainte, savez bien que celui qui a dit: tout m'est loisible, mais tout ne m'est pas expédient. Tâchez de faire trouver bon tout ce que le roi veut, non tout ce qu'il peut. ${ }^{40}$

De Morgues makes a very important distinction here that must not be overlooked at the risk of misunderstanding his thoughts on the distinction between power and will: “Vous n'établissez la grandeur que dans l'opinion et appréhension de la seule puissance on réduit toutes choses à l'autorité [...] on ne vous parle jamais de bonté, de clémence, de justice $[\ldots]$ on ne vous parle jamais [...] mais de sévérité, de rigueur et de force." ${ }^{41}$ Governing based on power is for him a form of tyranny, while governing based on will is

\footnotetext{
37 Séance royale dite de la flagellation, 557.

${ }^{38}$ Lim, "La pensée politique," 302-4.

${ }^{39}$ Ibid., 302.

${ }^{40}$ De Morgues, Vrais et bons avis d'un françois fidèle, 161.

${ }^{41}$ De Morgues, Très-humble remontrance au Roi, 43.
} 
just because it signifies governing in respect of the limits inherent in absolute monarchy. Bringing the king to govern according to his power and not his will thus constitutes an attack on his authority. ${ }^{42}$

However, de Morgues does stress that the king must impose his authority when circumstances require it. Contrary to what Seung Hwi Lim has suggested, de Morgues clearly defined what he meant by "grande extrémité." ${ }^{33}$ It meant the resistance to the king's decisions on the part of the Parlements which, implicitly, aimed to assume part of his power. In this case, the king can impose his authority on the Parlement. The right of remonstrance, here defined as a "tempérament d'artistocratie," never authorized the Parlements to limit the king's absolute authority. ${ }^{44}$ It is in this theoretical context that Mathieu de Morgues invalidated the monarchomach doctrine of the subjects' right to resist. And de Morgues stresses the firmness that the king showed towards the Huguenots in order to have his absolute power respected:

Notre roi, est celui de tous les princes chrétiens, qui les a poursuivis vivement [...] qui leur a ôté les biens des ecclésiastiques qu'ils possédaient en Béarn, et les a rendus aux évêques, aux abbés et aux prieurs. Qui a rétabli l'exercice de la religion catholique en plusieurs lieux d'où elle avait été bannie 50 ans [....] Qui a renversé l'autorité d'un Parlement, composé de personnes de religion contraire à la nôtre et en a établi des catholiques. Qui a mis entre ses mains les places les plus importantes [...] que la situation [...] aurait fait croire imprenable. Notre roi $[\ldots]$ a travaillé aux moyens de les réduire à l'obéissance entière [....] Il a [...] tâché de faire connaître, à ceux qui s'assemblaient contre ses volontés que cette entreprise lui déplaisait. Ayant vu leur obstination, et su les menées qu'ils faisaient dans son État, il a assemblé ses forces, dressé plusieurs armées, est allé dans la principale en personne, a retiré les places [....] A attaqué et battu celles qui ont résisté [....] En a fait ruiner quelques-unes des plus criminelles, et a châtié sévèrement ceux qui avaient été les auteurs de rébellion pour faire

\footnotetext{
42 “Sire, nous nous contenterions d'avoir découvert ce crime, que nous appellerons avec raison de lèse majesté au ler chef, puisqu'il tend à vous faire perdre l'affection de [...] tous vos peuples, et à les faire soulever contre vous": de Morgues, Très-humble remontrance au Roi, 44-5.

${ }^{43}$ Lim, “La pensée politique,” 306.

44 “Nous avons sujet de mettre au nombre des esprits faibles, ceux qui étant pourvus d'offices etdignités [...] se voudraient élever comme sales vapeurs, pour obscurcir la lumière du soleil. Je nem'adresse point à ce grand corps que je révère, et ne fait état que de parler à quelques particuliers. Cependant, on a remarqué en quelques magistrats des fausses générosités [...] que sous prétexte de corriger quelques manquements, voudraient entreprendre contre l'autorité royale, qui les a créés et les conserve. Comme il est à désirer que la cour ne rejette jamais, et même aime les remontrances, on doit aussi souhaiter que ceux, qui les peuvent faire, ne les convertissent pas toujours en plaintes, et jamais en faction, mais en propositions d'expédients, ou pour sortir d'un mal, ou pour avancer un bien, ou pour assister un prince, ou pour soulager le peuple": de Morgues, Bons avis sur plusieurs mauvais avis (1650), 19-20.
} 


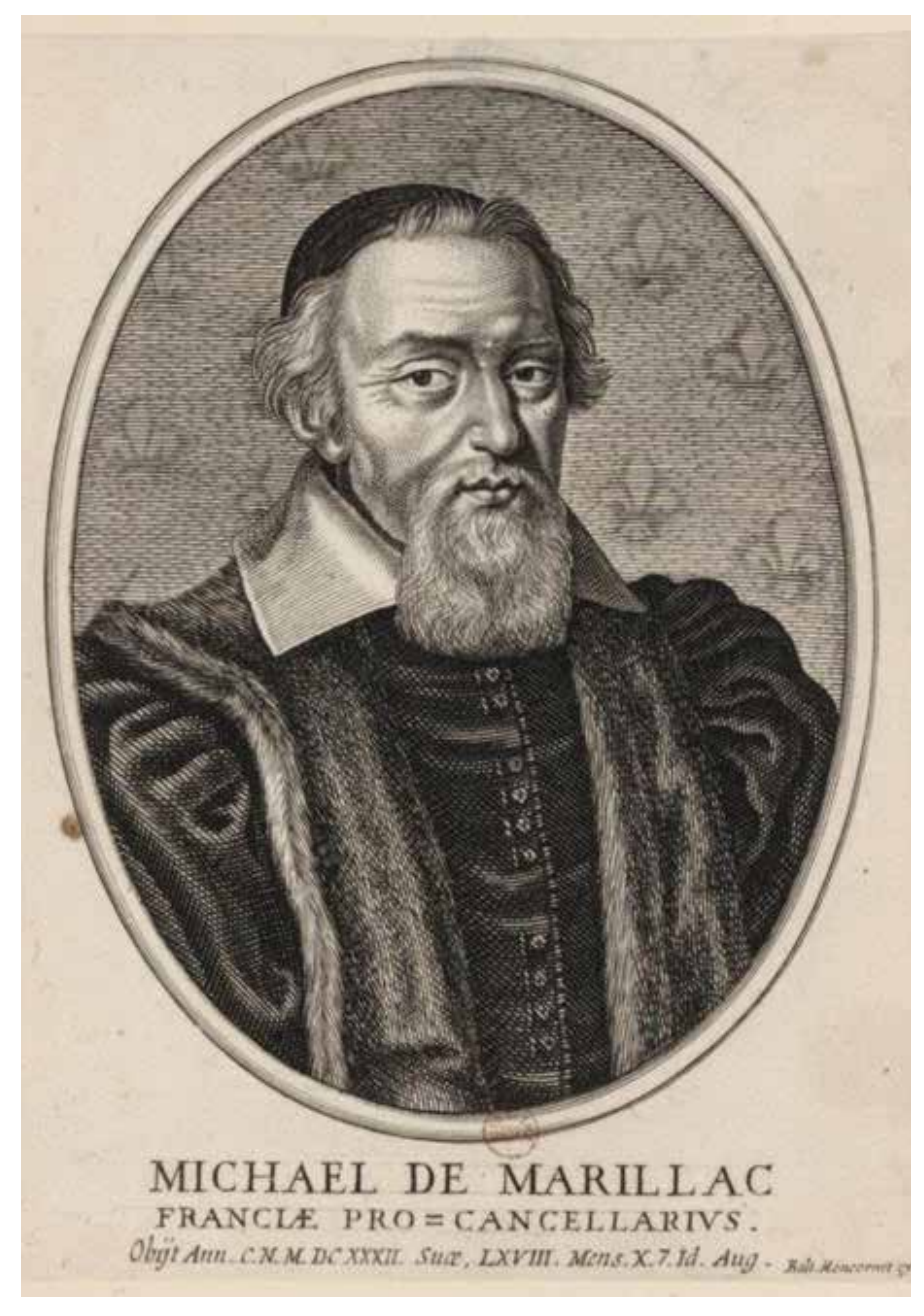

Engraved portrait of Michel de Marillac.

Artist unknown.

\section{Public Domain}

click to

enlarge

sentir la pesanteur de sa main de justice, à ceux qui avaient refusé la règle de son sceptre; et pour apporter quelque terreur de sa puissance, à ceux qui persistaient dans leur opiniâtreté..$^{45}$

In the same way, Mathieu de Morgues liked the king to decide for himself to exclude from government all those who sought to share an indivisible power, and in particular, his principal minister: “V.M. a de quoi tirer quelque avantage contre les ennemis de son État, de ce que je veux dire, et a moyen de leur faire voir votre puissance, lorsque j'aurai prouvé qu'un serviteur, avec ceux qui ont été en intelligence avec lui, vous a pris dans six ans plus de dix millions d'or [....] V.M [...] étant avertie [...] les arrêtera en ôtant par un arrêt sévère les comptants qui servent de couverture à tous les pillages." ${ }^{46}$ For de Morgues, favorites, even those who have great influence over the decision-making process, are mere pawns or chips that the king can make use of at his own discretion. ${ }^{47}$ This is but one more refutation of that theory of ministériat which gave the premier ministre a far more assured place than that of a fragile favorite who could be disposed of at any moment.

\footnotetext{
45 De Morgues, Advis d'un théologien sans passion (1626), 31-4.

46 De Morgues, Très-humble remontrance au Roi, 84, 99-100.

47 “Sire, voilà au vrai l'état où se trouve cette prodigieuse faveur [Richelieu] [...] Arrêtez-là, grand roi:faites lui connaître que vous pouvez la défaire aussi facilement comme vous l'avez faite": de Morgues, Très-humble remontrance au Roi, 104-5.
} 
In de Marillac's thought, the right of remonstrance enjoyed by the court of the Paris Parlement also corresponded to the maintenance of a limit appropriate to the spirit of absolute monarchy. Before the slightest conflict had erupted between himself and parlement regarding the registration of the reform ordinance of 1629, de Marillac had taken measures so that the Parlement would not use the right of remonstrance to weaken the authority of royal decisions. Indeed, the ordinance in question provided for a delay of six months before the sovereign courts could remonstrate against the king's edicts without, in the meantime, being able to suspend the execution of these edicts. ${ }^{48}$ Furthermore, if the courts considered that they had to remonstrate with the king, they could not hold up the registration of the decision for more than two months even if, after this time period, they had not remonstrated against it. ${ }^{49}$

These regulations did nothing to avoid inciting opposition from the Parlement, which was using the right of remonstrance to refuse to register Michel de Marillac's reform edict. For more than a century, the opposition of the Parlements had been based on their right of remonstrance, which allowed them to advise the king of faults of form and substance in legal texts submitted to them for registration. This prerogative was a result of the right of counsel, and Parlement, like the other sovereign courts, had long been very proud of it. As the permanent collaborators of the king in whose name they rendered justice and by whom they were consulted on important affairs, and as holders of important 'police' functions, the parlementaires tended to forget, from the reign of François I on, that they only exercised their functions by delegation from the king. The Parlements struggled regularly against royal power, abusing the right of remonstrance that preceded the registration of letters patent. Thus, they showed their desire to control the exercise of power and to share legislative power. Indeed, the parlementaires' attitude grew more rigid throughout the sixteenth century because of the increasing venality associated with hereditary functions, in the form of resignations from office in favor of a third party in return for payment. By the beginning of the seventeenth century, the parlementaires were feeling independent and secure in relation to the monarchy. They even claimed to be able to refuse to register a text, that is, to accept or reject laws. However, to silence the parlementaires' arrogance and put an end to the agitation that it created, the king had one useful tool: the lit de justice. ${ }^{50}$ This

\footnotetext{
48 "Permettons néanmoins aux gens tenant nos cours de Parlement et autres cours souveraines nous faire telles remontrances [....] dans six mois [....] Cependant, voulons nos dites ordonnances être observées, tant dans les jugements des procès qu'autrement, sans y contrevenir ni sans dispenser ou modérer les peines portées par icelles [...] même sous couleur desdites remontrances non faites" : Ordonnance sur les plaintes des états assemblés à Paris en 1614 et de l'assemblée des notables réunis à Rouen et à Paris, en 1617 et 1626, Jan. 1629 (ed. F.A. Isambert, Paris, 1829), xvi. 225-6.

49 “Enjoignons à toutes nos dites cours de procéder incessamment [...] à la publication des édits, ordonnances, lettres patentes qui leur seront par nous adressées [sic] si ce n'est que nos dites cours eussent quelques remontrances à nous faire sur aucun point desdits édits et ordonnances: lesquelles [sic] ils ne pourront réitérer dans deux mois au plus tard après la date de nos dits édits et lettres. Et après avoir entendu notre volonté sur icelles, nous voulons et ordonnons qu'il soit passé outre à la publication d'icelles toutes choses cessantes et sans aucune remise," Ordonnance sur les plaintes des états, 239.
}

${ }^{50}$ S. Hanley, Le Lit de justice des rois de France. L'idéologie constitutionnelle dans la légende, le rituel et le discours (Paris, 1991). 
involved the king's solemn appearance in the great chamber of the Parlement where he sat on a dais surrounded by both his judge-counselors and the most eminent personages of the kingdom, such as the chancellor, the peers of France, the grand officers and the members of the Hôtel du roi. When the king judged that the Parlement had exceeded its powers, he came to the chamber in person, thereby signifying that the edict submitted had to be registered forthwith, and forbidding the parlementaires to involve themselves with affairs of state. Given the parlementaires' opposition to the edict written by the garde des sceaux de Marillac, on 28 December 1628, a lit de justice was decided upon in agreement with de Marillac and Richelieu. The forced registration took place on 15 January 1629 and, in accordance with the spirit of the aforementioned edict, the king "fit dire par le garde des sceaux qui [sic] si la cour trouvait aux ordonnances quelques articles qui leur semblassent requérir quelques limitations ou interpretations, il aurait bien agréable d'en entendre quelques remonstrances." ${ }^{51}$ The magistrates had two months, "l'ordonnance demeurant cependant en sa force et sa vertu." Thus, the ordinance was already in force before the Parlement had either remonstrated against it or delivered the edict of registration. This maneuver infuriated the parlementaires and the first speaker of the Parlement de Paris threatened de Marillac with prosecution for violating the fundamental laws of the kingdom. For eight months, the Parlement refused to deliver to the garde des sceaux the copies of registration and verification and demanded that execution be delayed while it developed its remonstrances. All this time, de Marillac and the queen mother, who were in charge during the absence of the king and the cardinal at the siege of La Rochelle, kept demanding an edict of registration, even though the Parlement had still not presented its remonstrances, thus demonstrating that they had no power to delay the registration of an ordinance. De Marillac also drew up a memorandum in which he answered the Parlement's question on its authority, leaving no doubt about his position in favor of absolutism: "La puissance de nos rois est indépendante n'a [sic] nulle nécessité de prendre avis ou compagnie ou de personne aucune dans le royaume [...] Je ne voudrais pas abroger tout à fait cet usage de faire des remonstrances. Je sais bien que les rois doivent régner par justice." ${ }^{52}$ The stand-off lasted until the autumn, when it took another intervention of the king to obtain deliverance of the certificate of registration, on 5 September 1629.

This way of thinking about remonstrances is comparable to that regarding absolute monarchy. Thus, in the well-known sitting called the Flagellation, Louis XV recalled that the Parlement's remonstrances should not weaken royal decisions:

Les remonstrances sont toujours reçues favorablement quand elles ne respireront que cette moderation qui fait le caractère du magistrate et de la véritié quand le secret en conservera la décence et l'utilité, et quand cette voie si sagement établie ne se trouvera pas travestie en libelles, où la soumission à ma volonté est

\footnotetext{
51 Grillon, Les Papiers de Richelieu, iv (1629), 619-20.

52 Marillac, Mémoire contre l'autorité du Parlement, fos 91v-93v.
} 


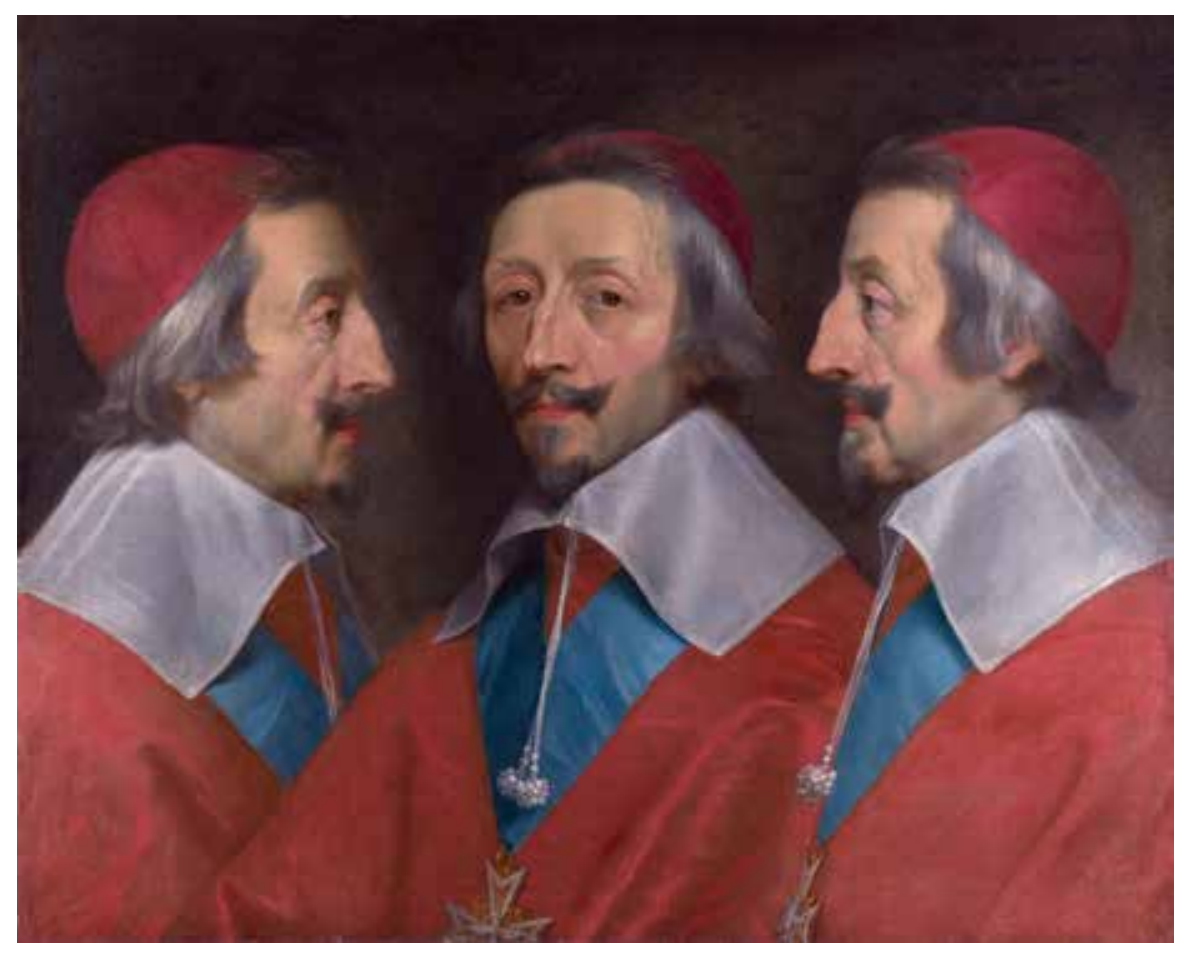

An elaborate portrait of Cardinal Richelieu, believed 1642, by Philippe de Champaigne. Possibly done to aid in the creation of a bust, given the multiple perspectives.

Public Domain

click to

enlarge

présentée comme un crime et l'accomplissement des devoirs que j'ai prescrits, comme un sujet d'opprobre où l'on suppose que toute la nation gémit de voir ses droits, sa liberté sa sûreté, prêts à périr sous la force d'un pouvoir terrible, et où l'on annonce que les liens de l'obéissance sont prêts à se relâcher. ${ }^{53}$

The sovereign considered that this concept belonged to the essence of the monarchy. Indeed, if the parlementaires used their right to limit the king's power, they changed monarchy into anarchy:

Mais si, après que j'ai examiné ces remontrances et qu'en connaissance de cause je persiste dans mes volontés, mes cours persévéraient dans le refus de s'y soumettre au lieu d'enregistrer du très exprès commandement du roi, formule usitée pour exprimer le devoir d'obéissance, si elles entreprenaient d'anéantir par leur seul effort des lois enregistrées solennellement, si enfin lorsque mon autorité a été forcée de se déployer dans toute son étendue, elles osaient encore lutter en quelque sorte contre elle, par des arrêts de défense, par des oppositions successives ou par des voies irrégulières de cessation de service ou de démissions, la confusion et l'anarchie prendraient la place de l'ordre légitime, et le spectacle scandaleux d'une contradiction rivale de ma puissance souveraine me réduirait à la triste nécessité d'employer tout le pouvoir quej'ai reçu de Dieu pour préserver mes peuples des suites funestes de ces entreprises. ${ }^{54}$

\footnotetext{
53 Séance royale dite de la flagellation, 558.

54 Ibid.
} 
More exactly, this version of the right of remonstrance is based on the idea of the indivisibility of sovereignty. De Marillac continued the demonstration of his attachment to the regime of absolute monarchy in his Discours sur le bon gouvernement, insisting on the fact that the king always had to keep the reins of power in his hands. In this unpublished speech given in June 1630, Marillac defines 'good government' as that in which the king holds and exercises power alone, and insists that the king must let no one else usurp his power. This applies to all the orders and bodies of the kingdom, including the Parlement and the premier ministre. In this speech, given a few months after the Day of the Dupes, Michel de Marillac declared himself clearly opposed to Cardinal Richelieu's ministériat. ${ }^{55}$

\section{IV}

The dévot Catholic party's thinking thus illustrates the idea that absolute monarchy retained its natural limits, and that this distinguished it from tyranny. These limits were not impediments on its power but rather characteristics of it. In this light, the interpretation of the dévots' thought takes on a completely different interpretation, namely the one that the great absolutist thinkers gave to monarchy. Indeed, if Jean Bodin and Cardin le Bret envisaged limits on the exercise of sovereignty, they can nevertheless be considered pure absolutists, favorable to rationalism. ${ }^{56}$ Far from putting absolute monarchy in question, the limits that Jean Bodin assigned to the exercise of sovereign power were compatible with the idea of absolute sovereignty and did not restrict it. ${ }^{57}$ Indeed, Bodin explained that the sovereign courts' right of remonstrance is part of the monarchical regime although, given the indivisibility of sovereignty, the right of remonstrance cannot hinder the promulgation of a law:

Si donc le mandement du prince n'est point contraire aux lois de la nature, le magistrat le doit exécuter [...]. Mais si le magistrate connaît que le prince casse le plus juste et plus profitable edit pour donner lieu au moins juste et moins profitable au public, il peut tenir l'exécution de l'édit ou mandement en souffrance, jusqu'à ce qu'il ait fait ses remonstrances, comme il est tenu de le faire, non pas une, mais deux et trois fois: et si nonobstant ces remonstrances le prince veut qu'il soit passé outre, alors le magistrat le doit exécuter, voire dès la première jussion, si le délai était périlleux. ${ }^{58}$

Far from suffering from the emancipation of the political sphere, religion, too, can be considered as an essential characteristic of the theory of sovereignty: "Quant aux lois divines et naturelles, tous les princes souverains de la terre y sont sujets, et n'est pas en leur

\footnotetext{
${ }^{55}$ Maillet-Rao, “La théologie politique des dévots," 55-7, 65-6.

${ }^{56}$ Contra Picot, Cardin le Bret, 199; S. Goyard-Fabre, Jean Bodin et le droit de la République (Geneva, 1974 edn), 160-2.

${ }^{57}$ Contra Goyard-Fabre, Jean Bodin, 164. J. H. Franklin, Jean Bodin et la naissance de la théorie absolutiste (Paris, 1993 edn), 166.

${ }^{58}$ Bodin, Les six livres de la République, i, ch. 4, 98.
} 
puissance d'y contrevenir s'ils ne veulent être coupables de lèse-majesté divine, faisant guerre à Dieu, sous la grandeur duquel tous les monarques du monde doivent faire joug, et baisser la tête en toute crainte et révérence. ${ }^{\prime 59}$ Despite the limits comprised by the right of remonstrance and religion, sovereignty is still defined as the exclusivity of the exercise of power. ${ }^{60}$ Sovereignty can also be characterized as being anchored strictly in the king's will: “La première marque du prince souverain, c'est la puissance de donner loi [...] mais ce n'est pas assez, car il faut ajouter, sans le consentement de plus grand ni de pareil ni de moindre que soi: car si le prince est oblige de ne faire loi sans le consentement d'un plus grand que soi, il est vrai sujet: si d'un pareil, il aura compagnon: si des sujets, soit du sénat, ou du people, il n'est pas souverain." ${ }^{\prime 1}$ Definitively, absolute sovereignty carries intrinsic restrictions that preclude neither its absolute character nor its exclusive exercise.

As for Cardin le Bret, he showed little prudence in according a right of remonstrance to the sovereign courts. On the contrary, the limits implied by the necessity of being just and prudent belonged to the spirit of the monarchical state, for they never put the king's absolutism in doubt. ${ }^{62}$ Indeed, for Cardin Le Bret, it was sovereignty that limited the sovereign courts' right of remonstrance. They could remonstrate energetically, however, the sovereign courts must stop as soon as the king manifested his wish either to modify the law or to be obeyed. In this latter case, the courts would have no other choice than to register the edict:

On peut encore demander quelle obéissance les cours souveraines doivent rendre aux édits que le roi leur envoie pour les registrer et publier je n'entends pas parler de ceux qui sont justes, d'autant que chacun doit aller au devant, et les recevoir comme des oracles, mais de ceux qu'on appelle bursaux, comme s'il voulait augmenter ses tribus, en établir de nouveaux, et créer des officiers inutiles et superflus, pour en tirer de l'argent. Il me semble qu'il faut distinguer les temps [...] hors le cas de nécessité, j'estime qu'il y va de la réputation des cours souveraines de faire au prince de sérieuses remontrances, et tâcher par toutes sortes de moyens de le détourner de tels conseils [....] Mon opinion est que les compagnies souveraines doivent persévérer, jusqu'à ce qu'elles aient obtenu quelque chose, ou qu'ils en aient du tout perdu l'espérance. Car alors il se faut résoudre à l'obéissance [...]; autrement la majesté et l'autorité royale seraient par ce moyen sujettes aux volontés de ses officiers, ce qui serait trop préjudiciable à l'État du prince souverain. ${ }^{63}$

\footnotetext{
${ }^{59}$ J.-F. Courtine, “L'héritage scolastique dans la problématique théologicopolitique de l'âge classique," L'État baroque (Paris, 1985), 97. Bodin, Les Six livres de la République, i, ch. 8, 192-3.

${ }^{60}$ B. Barret-Kriegel, in Les Chemins de l'État (Paris, 1986), i. 33.

${ }^{61}$ Beaud, La puissance de l'État, 57. Bodin, Les Six livres de la République, i, ch. 10, 306.

${ }^{62}$ Contra Picot, Cardin Le Bret, 192-8, and Thuau, Raison d'État, 277.

${ }^{63}$ Le Bret, De la souveraineté du roi, 60-1.
} 


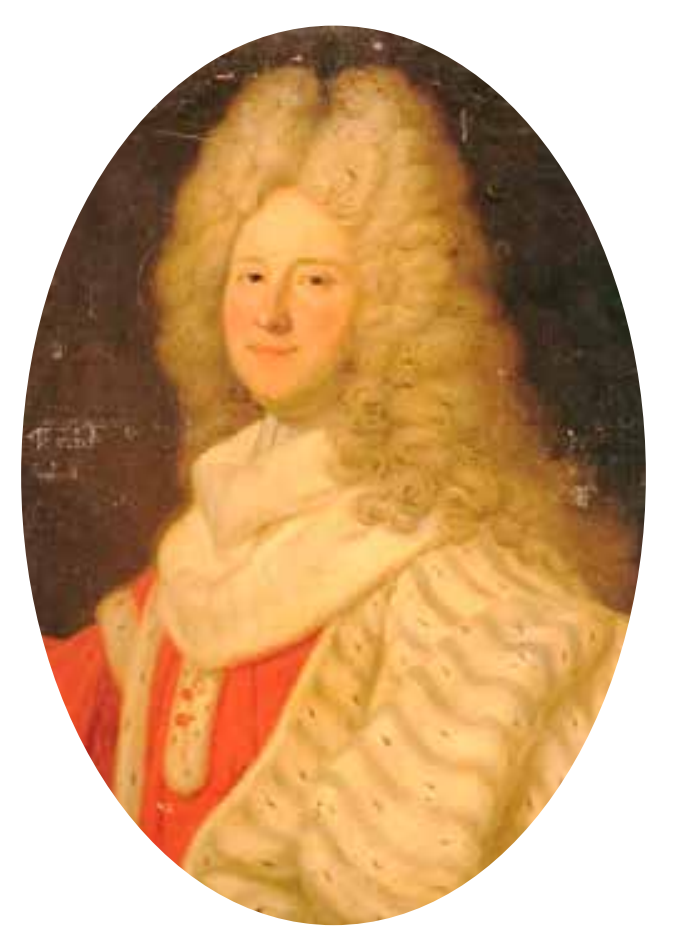

Pierre-Cardin Le Bret (1639-1710).

Public Domain

click to

enlarge

Thus, the right of remonstrance was not really constraining for royal power. Furthermore, Le Bret added that if the courts found that the king was not disposed to hear the slightest remonstrance, they would not only have to abstain from making any, they would also have to register the edict immediately. ${ }^{64}$ And neither did the necessity of governing justly distort the king's absolute sovereignty, since the king held this power in order to give justice to their [sic] people. ${ }^{65}$ Besides, kings were the only ones able to modify existing laws when justice demanded it: "Les rois peuvent user de leur puissance et changer les lois et ordonnances anciennes de leur État [...], quand la nécessité et la justice le désirent. Il n'appartient aussi qu'aux princes d'expliquer le sens des lois, et de leur donner telle interprétation qu'ils veulent [...]. Mais le sage prince doit prendre soigneusement garde, en usant de cette puissance, de ne pas forcer le vrai sens des lois, et de leur donner une interprétation contraire à la justice et à l'intention de leur auteur." ${ }^{\prime 66}$ Cardin Le Bret adds a check to the king's absolute sovereignty, the same one that Mathieu de Morgues outlined in his exposé on government, consisting of the notion that the king used his absolute power only when the circumstances required it in order to remain loved by his subjects.

If we can consider Richelieu as a 'true absolutist,' it is not because he recognized no limit to the king's sovereign power. It is true that, contrary to his contemporaries Jean Bodin and Cardin Le Bret, Richelieu does not, in principle, accord any right of remonstrance to the sovereign courts so as not, he explains, to take the risk of harming the king's authority.

Il semble qu'il y ait beaucoup à dire sur un tel sujet et cependant j'en dirai assez en trois mots, si je mets en avant qu'il ne faut autre chose que restreindre les officiers de justice à ne se mêler que de la rendre aux sujets du Roi, qui est la

\footnotetext{
${ }^{64}$ Ibid., 61.

${ }^{65}$ Ibid., 18.

${ }^{66}$ Ibid., 19.
} 


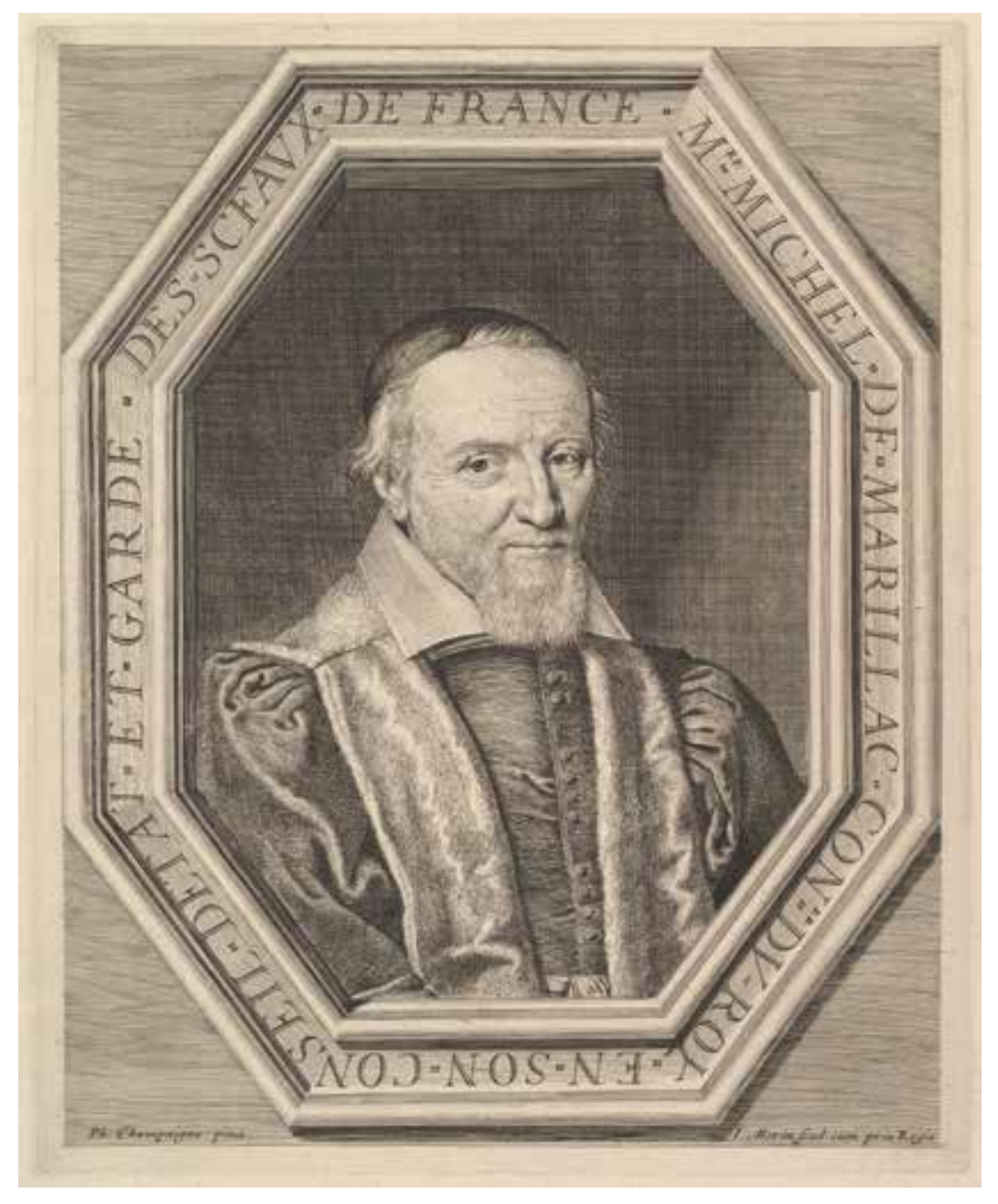

Michel de Marillac, conseiller d'etat et garde des sceaux. Etching by Jean Morin.

Public Domain

click to

enlarge

seule fin de leur établissement c'est une chose si importante que, si on laissait aller la bride à ces compagnies puissantes, on ne pourrait plus après les tenir dans les bornes de leur devoir. Il serait impossible d'empêcher la ruine de l'autorité royale si on suivait les sentiments de ceux qui, étant aussi ignorants dans la pratique du gouvernement des États comme ils présument être savants dans la théorie de leur administration, ne sont ni capables de juger solidement de leur conduite, ni propres à donner des arrêts sur le cours des affaires publiques qui excèdent leur portée. Comme il ne faut rien souffrir des compagnies qui blessent l'autorité souveraine. ${ }^{67}$

In fact, the cardinal went so far as to recommend tolerating critics who did not undermine the king's power:

C'est prudence de tolérer quelques uns de leurs défauts en autre genre. Il faut compatir aux imperfections. Il n'y a personne qui ne doive improuver leur procédé quand ils sont emportés par quelques dérèglements, mais, en le condamnant avec raison, il est difficile d'y trouver remède [....] C'est chose si ordinaire à telles compagnies de regarder et trouver à redire au gouvernement des États que cela ne doit pas sembler étrange. Toute autorité subalterne regarde toujours

\footnotetext{
${ }^{67}$ Richelieu, Testament politique, part I, ch. 4, section 3, critical edition published with an introduction and notes by F. Hildesheimer (Paris, 1995 edn), 175.
} 
avec envie celle qui lui est supérieure; comme elle n'ose disputer la puissance, elle se donne la liberté d'en décrier la conduite. Il n'y a point d'esprits si réglés à qui la domination la plus douce ne soit en quelque façon odieuse. ${ }^{68}$

On the other hand, the cardinal did not ask the question whether the great power that he accorded to the principal minister "blesserait l'autorite du roi." And yet, the constitutive principles of the theory of ministériat appear shocking to a 'pur absolutist,' as Mathieu de Morgues' criticisms of Richelieu have shown.

For several decades, historiography presented the dévots in essentially the same way as had Richelieu, their adversary. But can we trust a portrait that someone paints of his adversaries, especially in politics? This analysis reveals that, contrary to the commonlyaccepted idea, the dévots did not defend the model of limited monarchy. They had always defended and respected the king's absolute power. Their criticism against ministériat was formulated within the limits imposed by the representative of the sovereign power: the right of remonstrance. Not once did Michel de Marillac ever issue an opinion without being solicited by the king. During the pamphlet war opposing the dévot party and Richelieu's advocates in the wake of the Day of the Dupes, Mathieu de Morgues addressed no more than a single pamphlet to Louis XIII. The pamphlet was framed as a remonstrance entitled Très-humble, très-véritable et très-importante remontrance au roi (1631). The other pamphlets, also mostly from 1631, targeted specifically the cardinal's supporters as attested to by their titles. ${ }^{69}$ Just like Richelieu, de Morgues and de Marillac were absolutists; hence their opposition to the ministériat.

\footnotetext{
68 Richelieu, Testament politique, 176.

69 Vrais et bons avis d'un français fidèle. Sur les calomnies et blasphèmes du sieur des Montagnes, ou Examen du libelle intitulé, Défense du Roy et de ses ministres; Charitable remontrance de Caton chrestien au Cardinal de Richelieu; Advertissement de Nicocléon à Cléonville, sur son advertissement aux provinces; Réponse à la seconde lettre que Balzac a fait imprimer avec son prince (1632).
} 


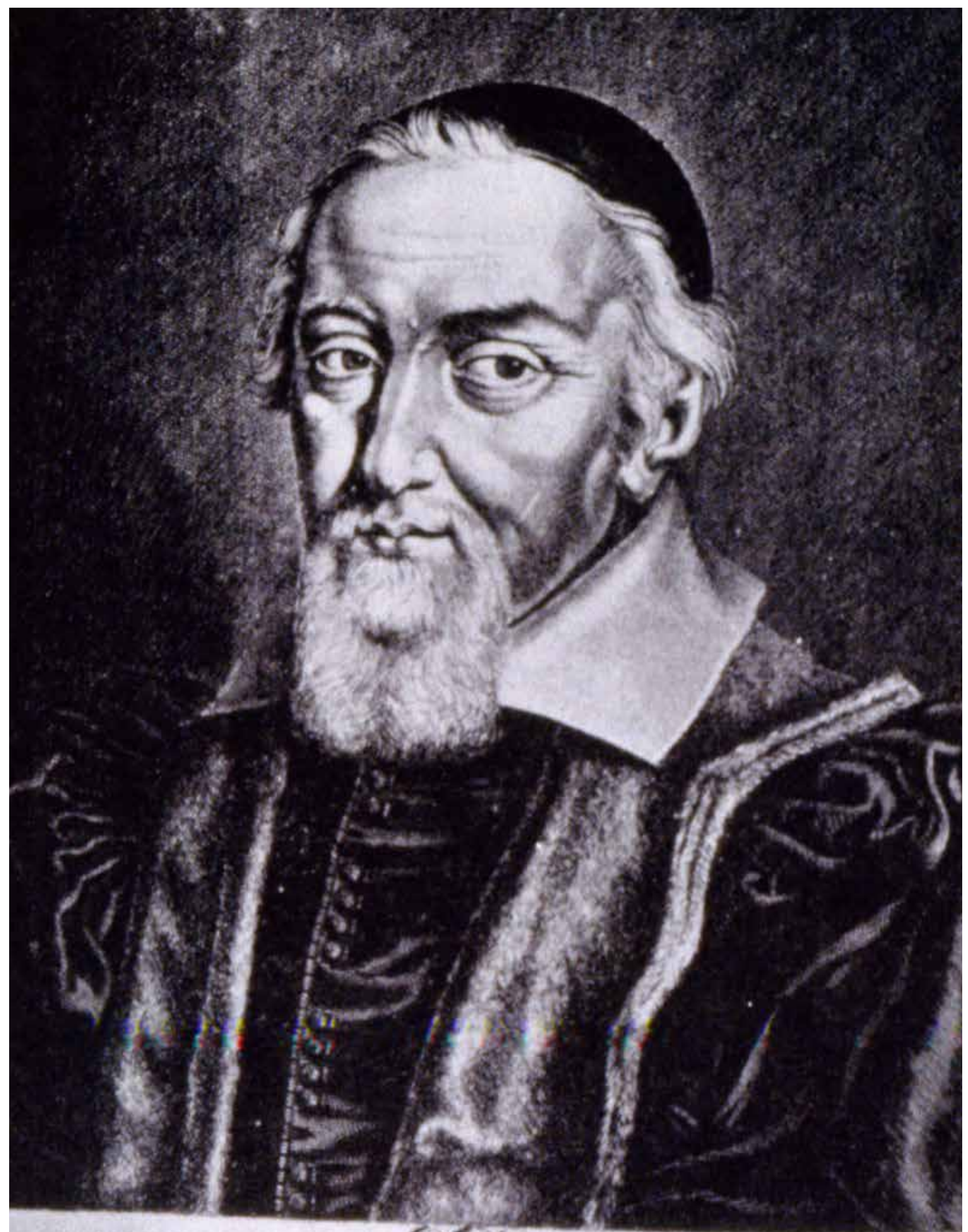

\section{MICHAEL DE CESOE MARIIIAC \\ FRANCIE PRO $05(6)$ (5).CANCELLARIVS

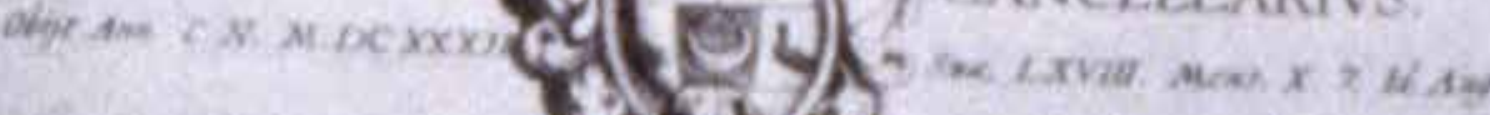

Portrait of Michel de Marillac (1560-1632).

Image collection of the Vincentian Studies Institute

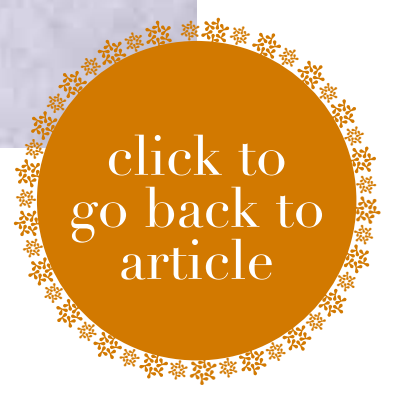




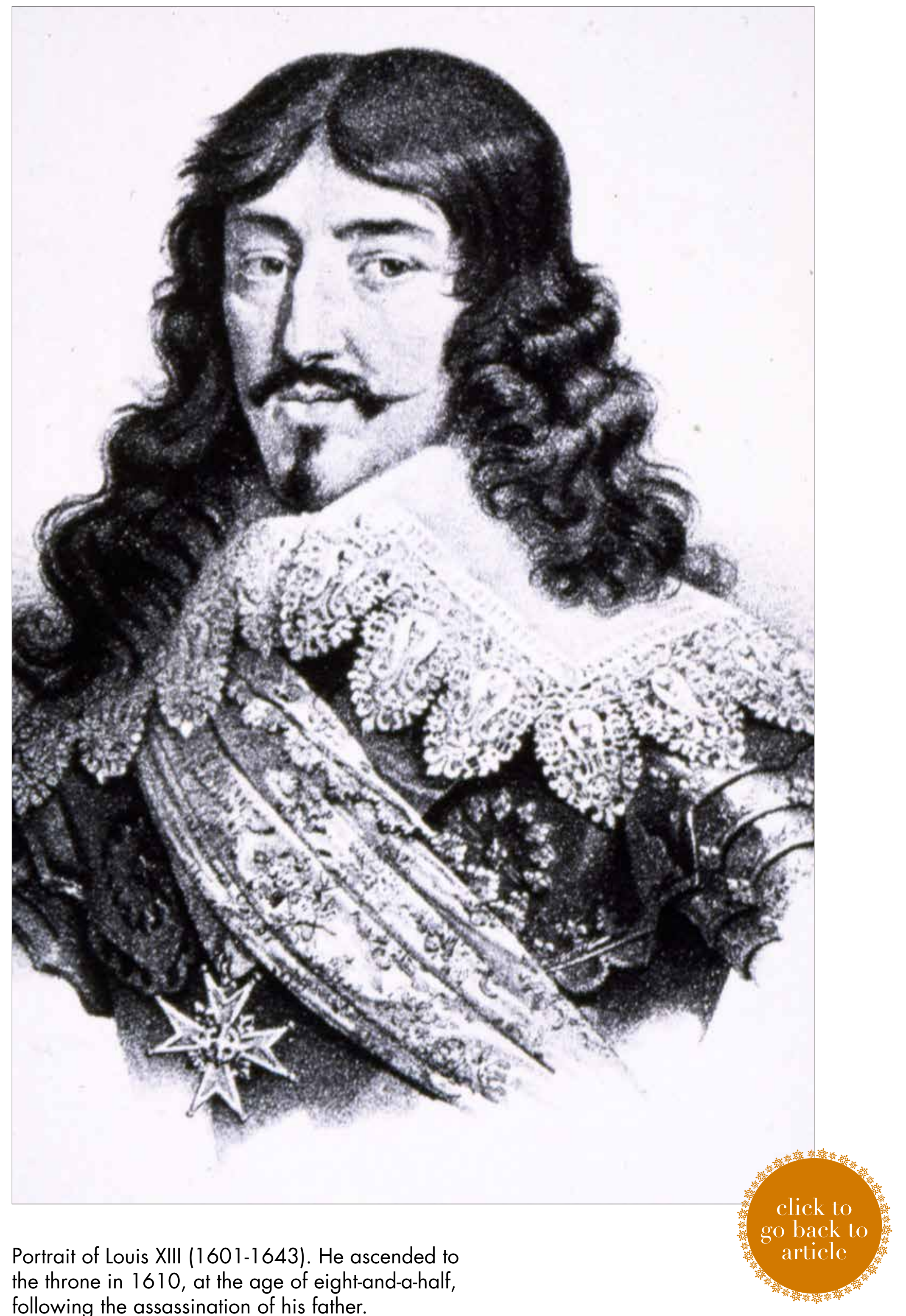

Image collection of the Vincentian Studies Institute 


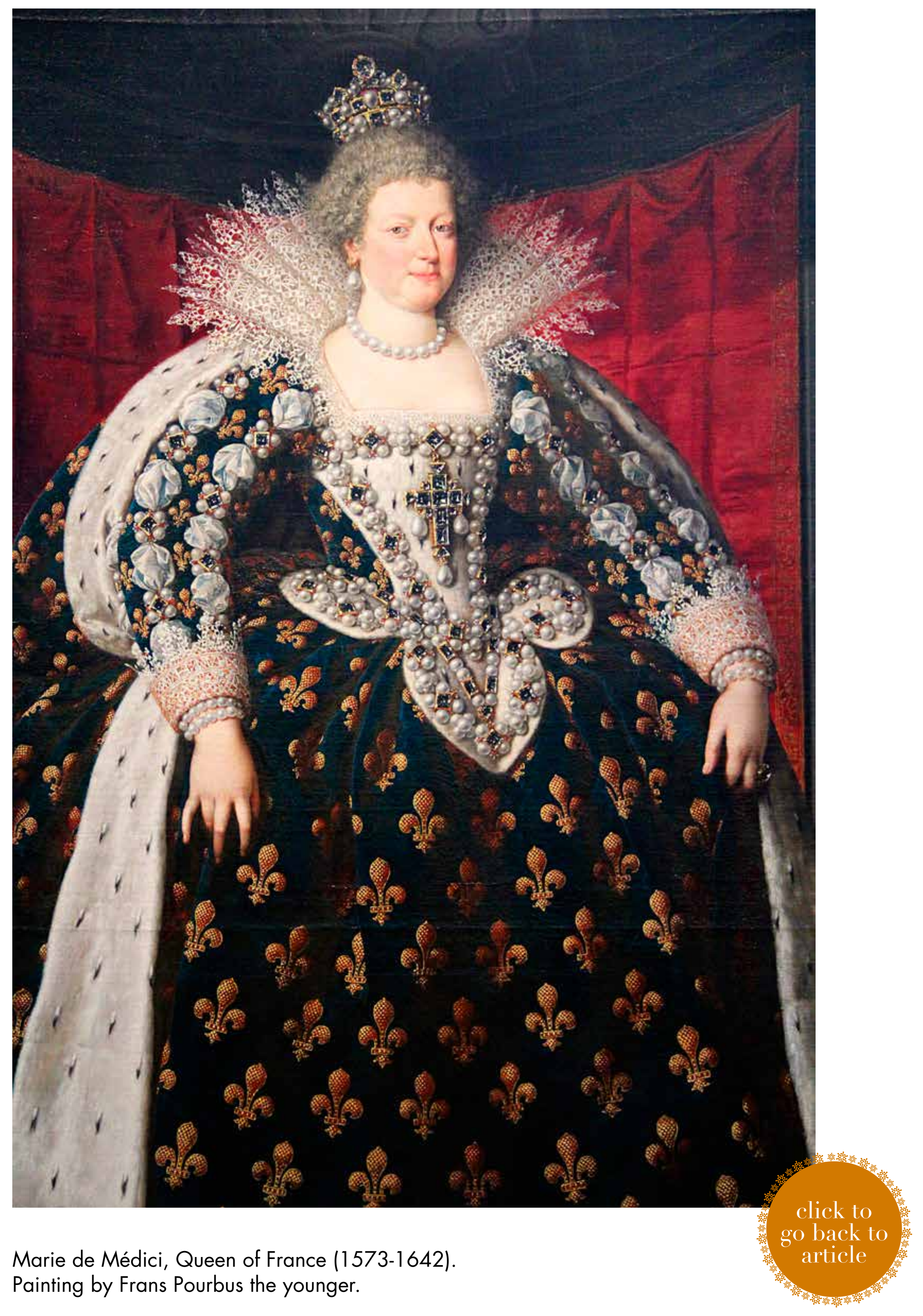

Public Domain 


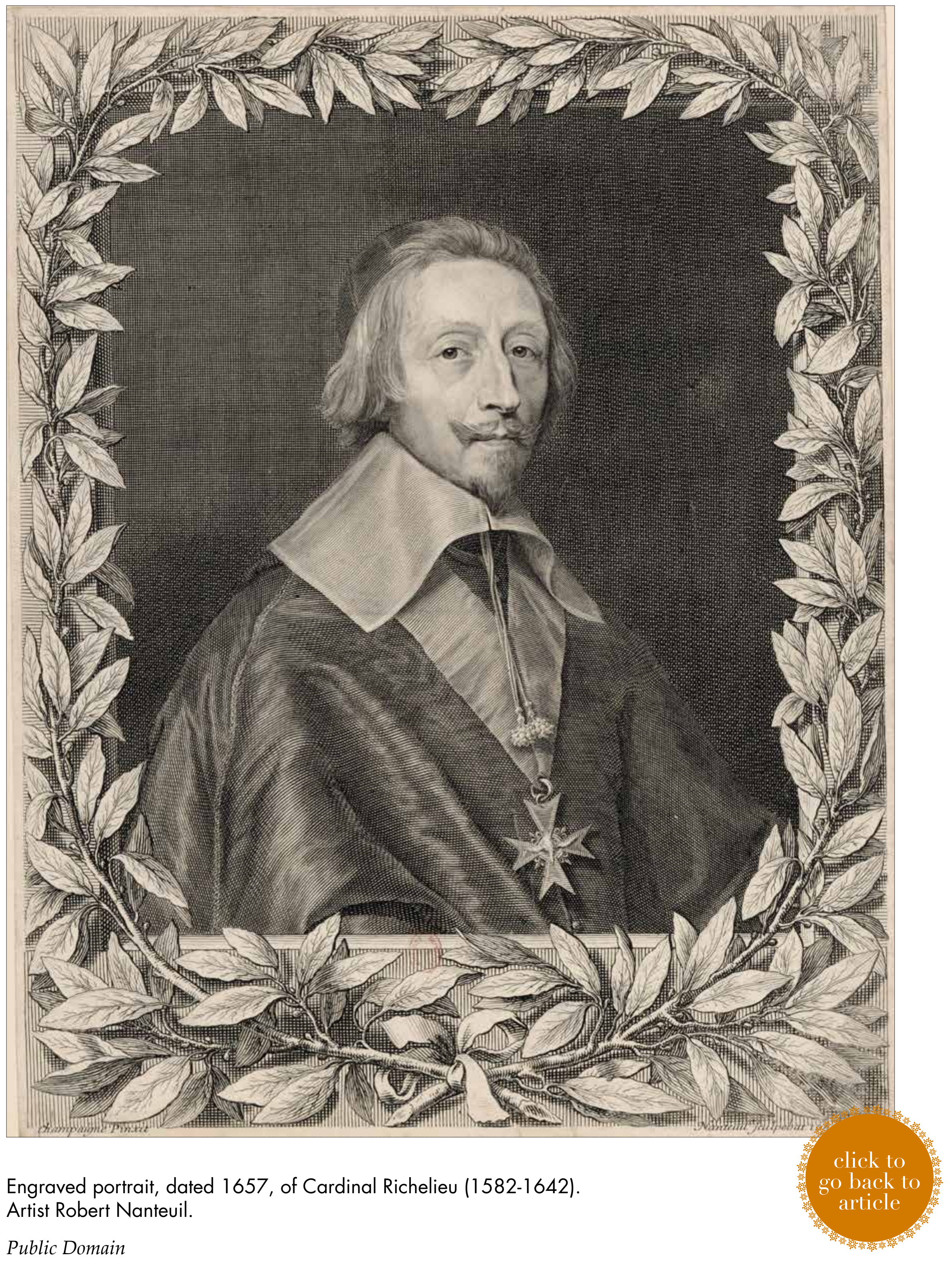




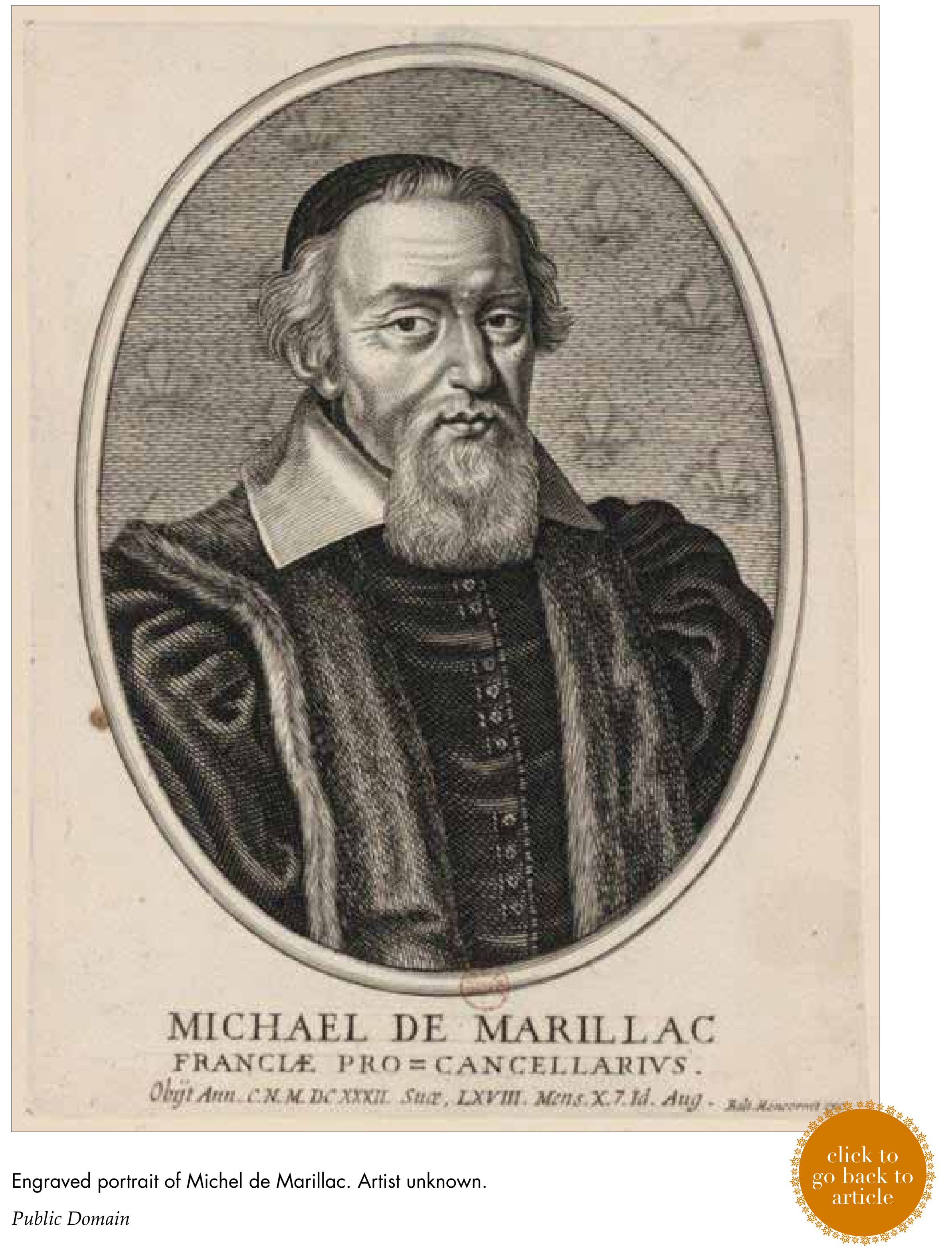




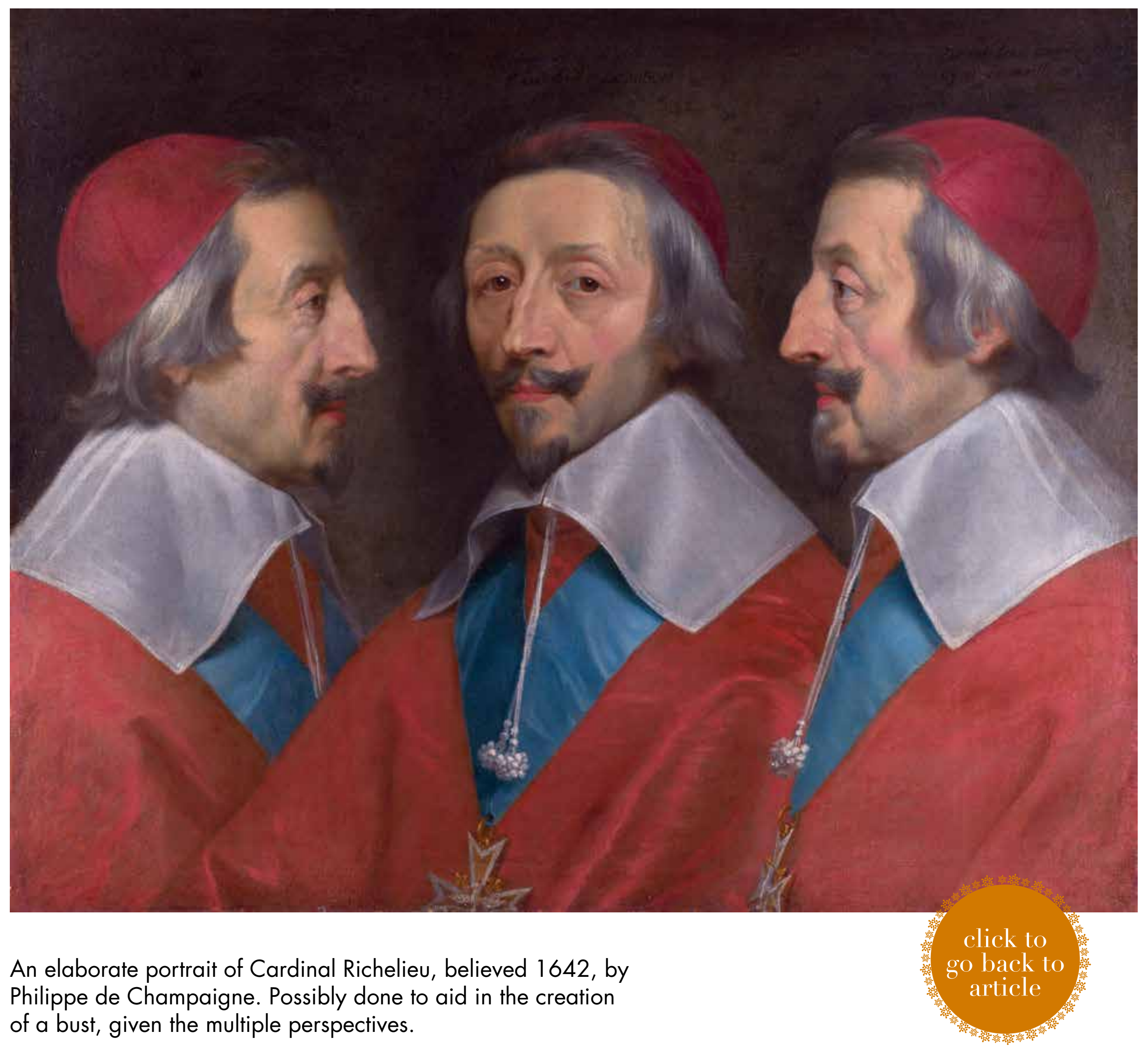

Public Domain 


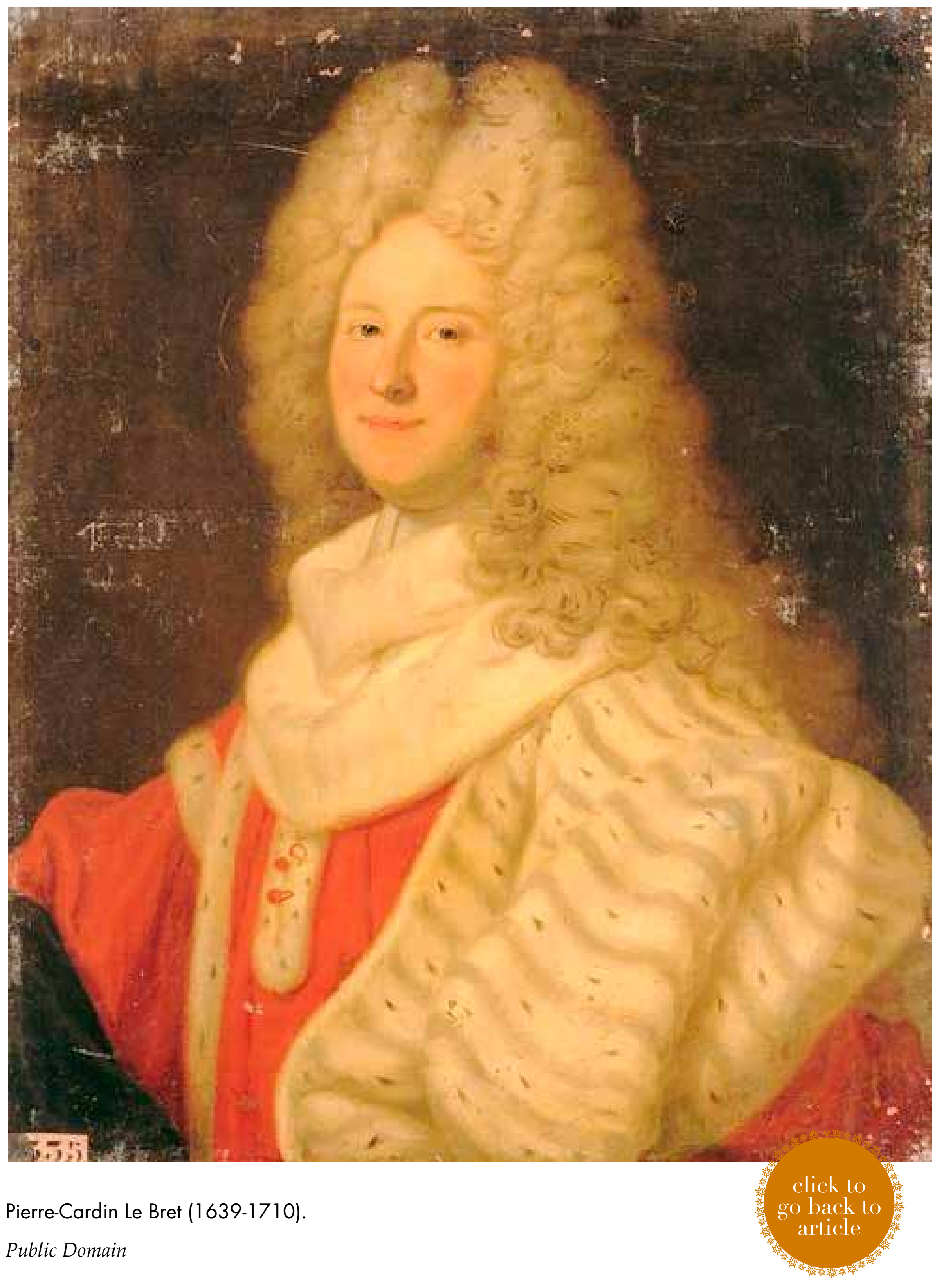




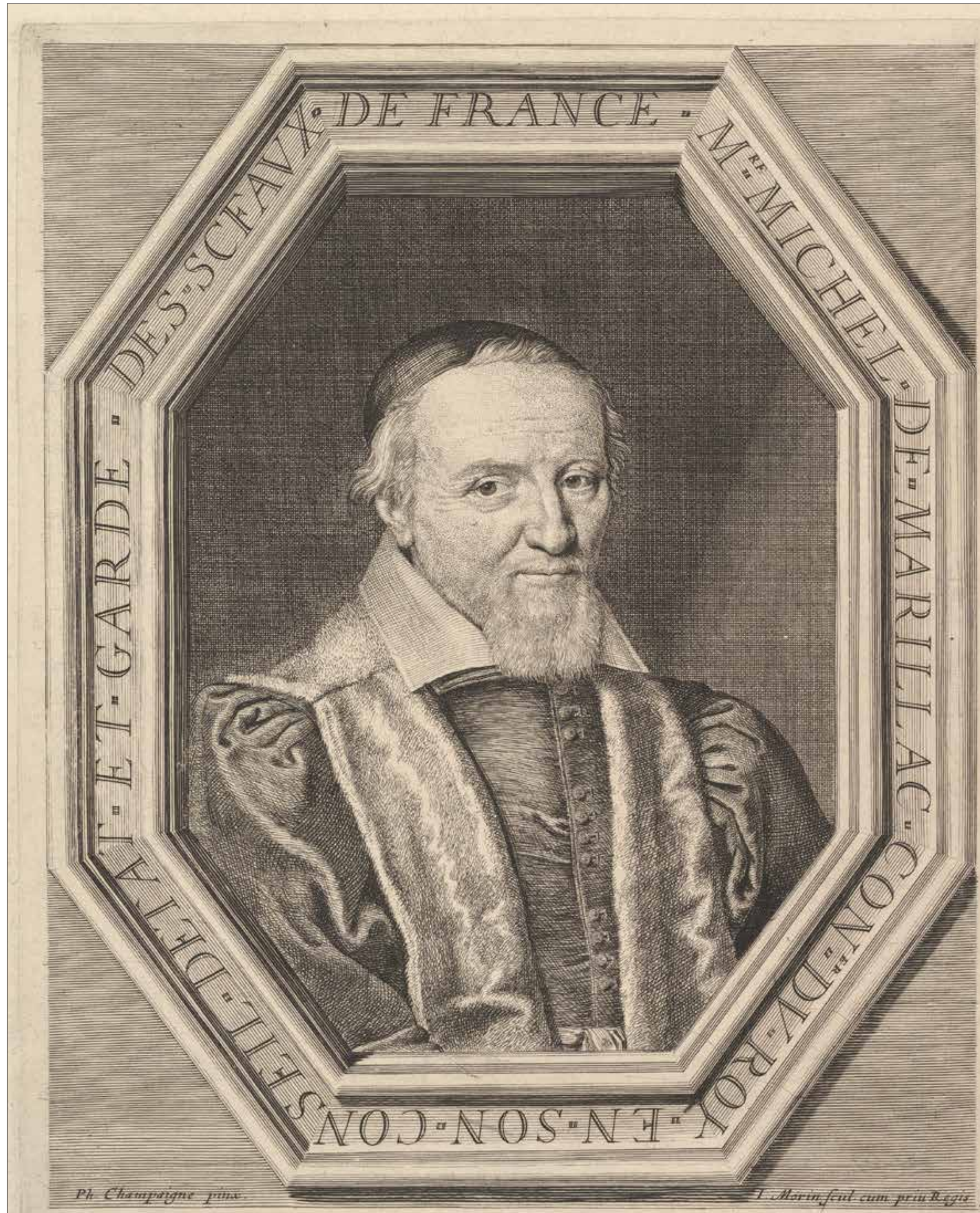

Michel de Marillac, conseiller d'etat et garde des sceaux. Etching by Jean Morin.

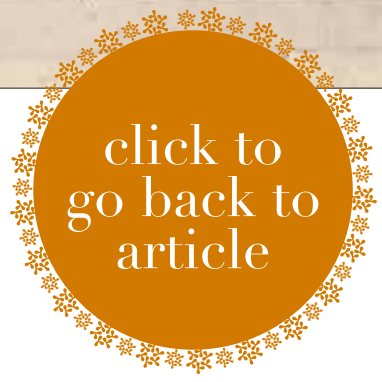

